\title{
Measurements of nitrite production in and around the primary nitrite maximum in the central California Current
}

\author{
A. E. Santoro ${ }^{1}$, C. M. Sakamoto ${ }^{3}$, J. M. Smith ${ }^{2}$, J. N. Plant ${ }^{3}$, A. L. Gehman ${ }^{3,4}$, A. Z. Worden $^{3}$, K. S. Johnson ${ }^{3}$, \\ C. A. Francis ${ }^{2}$, and K. L. Casciotti ${ }^{2}$ \\ ${ }^{1}$ Horn Point Laboratory, University of Maryland Center for Environmental Science, Cambridge, Maryland 21613, USA \\ ${ }^{2}$ Monterey Bay Aquarium Research Institute, Moss Landing, California 95039, USA \\ ${ }^{3}$ Department of Environmental Earth System Science, Stanford University, Stanford, California 94305, USA \\ ${ }^{4}$ Present address: Odum School of Ecology, University of Georgia, Athens, Georgia 30602, USA
}

Correspondence to: A. E. Santoro (asantoro@umces.edu)

Received: 15 March 2013 - Published in Biogeosciences Discuss.: 26 March 2013

Revised: 22 September 2013 - Accepted: 9 October 2013 - Published: 19 November 2013

\begin{abstract}
Nitrite $\left(\mathrm{NO}_{2}^{-}\right)$is a substrate for both oxidative and reductive microbial metabolism. $\mathrm{NO}_{2}^{-}$accumulates at the base of the euphotic zone in oxygenated, stratified openocean water columns, forming a feature known as the primary nitrite maximum (PNM). Potential pathways of $\mathrm{NO}_{2}^{-}$ production include the oxidation of ammonia $\left(\mathrm{NH}_{3}\right)$ by ammonia-oxidizing bacteria and archaea as well as assimilatory nitrate $\left(\mathrm{NO}_{3}^{-}\right)$reduction by phytoplankton and heterotrophic bacteria. Measurements of $\mathrm{NH}_{3}$ oxidation and $\mathrm{NO}_{3}^{-}$reduction to $\mathrm{NO}_{2}^{-}$were conducted at two stations in the central California Current in the eastern North Pacific to determine the relative contributions of these processes to $\mathrm{NO}_{2}^{-}$ production in the PNM. Sensitive $\left(<10 \mathrm{nmol} \mathrm{L}^{-1}\right)$, precise measurements of $\left[\mathrm{NH}_{4}^{+}\right]$and $\left[\mathrm{NO}_{2}^{-}\right]$indicated a persistent $\mathrm{NH}_{4}^{+}$maximum overlying the PNM at every station, with concentrations as high as $1.5 \mu \mathrm{mol} \mathrm{L} \mathrm{L}^{-1}$. Within and just below the PNM, $\mathrm{NH}_{3}$ oxidation was the dominant $\mathrm{NO}_{2}^{-}$producing process, with rates of $\mathrm{NH}_{3}$ oxidation to $\mathrm{NO}_{2}^{-}$of up to $31 \mathrm{nmol} \mathrm{L}^{-1} \mathrm{~d}^{-1}$, coinciding with high abundances of ammonia-oxidizing archaea. Though little $\mathrm{NO}_{2}^{-}$production from $\mathrm{NO}_{3}^{-}$was detected, potentially nitrate-reducing phytoplankton (photosynthetic picoeukaryotes, Synechococcus, and Prochlorococcus) were present at the depth of the PNM. Rates of $\mathrm{NO}_{2}^{-}$production from $\mathrm{NO}_{3}^{-}$were highest within the upper mixed layer $\left(4.6 \mathrm{nmol} \mathrm{L}^{-1} \mathrm{~d}^{-1}\right)$ but were either below detection limits or 10 times lower than $\mathrm{NH}_{3}$ oxidation rates around the PNM. One-dimensional modeling of water column $\mathrm{NO}_{2}^{-}$production agreed with production determined
\end{abstract}

from ${ }^{15} \mathrm{~N}$ bottle incubations within the PNM, but a modeled net biological sink for $\mathrm{NO}_{2}^{-}$just below the PNM was not captured in the incubations. Residence time estimates of $\mathrm{NO}_{2}^{-}$within the PNM ranged from 18 to 470 days at the mesotrophic station and was 40 days at the oligotrophic station. Our results suggest the PNM is a dynamic, rather than relict, feature with a source term dominated by ammonia oxidation.

\section{Introduction}

Nitrite $\left(\mathrm{NO}_{2}^{-}\right)$sits at the center of the nitrogen cycle. It fuels microbial metabolism as an intermediate in both nitrification and denitrification, and is a substrate for anaerobic ammonium oxidation (anammox). $\mathrm{NO}_{2}^{-}$is also reactive abiotically, reacting with sunlight (Zafiriou and True, 1979b; Zafiriou and Mcfarland, 1981), potentially forming trace amounts of climate-relevant radical species (Zafiriou and True, 1979a; $\mathrm{Su}$ et al., 2011), and undergoing oxygen isotope exchange with water (Casciotti et al., 2002, 2007; Buchwald et al., 2012; Buchwald and Casciotti, 2013). Despite its biological and chemical reactivity, $\mathrm{NO}_{2}^{-}$accumulates to appreciable levels in marine oxygen-deficient zones (Codispoti et al., 1986; Ward and Zafiriou, 1988) where it is thought to indicate incomplete denitrification. $\mathrm{NO}_{2}^{-}$also accumulates at the base of the euphotic zone in oxygenated, stratified open-ocean water columns, forming a feature known as the primary nitrite maximum (PNM, reviewed by Lomas and 
Lipschultz, 2006; Karl et al., 2008) ranging in magnitude from tens of $\mathrm{nmol} \mathrm{L}^{-1}$ in the oligotrophic gyres (Wada and Hattori, 1971; Dore and Karl, 1996b; Raimbault et al., 2008) to several $\mu \mathrm{mol} \mathrm{L}^{-1}$ in productive coastal upwelling areas (Codispoti et al., 1986; Naqvi et al., 1998; Newell et al., 2011).

Potential pathways of $\mathrm{NO}_{2}^{-}$production in aerobic waters include the oxidation of ammonia $\left(\mathrm{NH}_{3}\right)$ by ammoniaoxidizing bacteria (AOB) and archaea (AOA) (Ward, 2002) as well as assimilatory $\mathrm{NO}_{3}^{-}$reduction by phytoplankton (Kiefer et al., 1976) and heterotrophic bacteria (Allen et al., 2001). The relative roles of these two pathways in the formation of the PNM have been extensively debated (Brandhorst, 1959; Vaccaro and Ryther, 1960). Proposed mechanisms for the maintenance of the PNM usually invoke organismal responses to sunlight - either insufficient light energy for complete phytoplankton nitrogen assimilation (Lomas and Lipschultz, 2006) or light inhibition of nitrite oxidation (Olson, 1981b). Others have suggested that it is actually the availability of sufficient light and $\mathrm{NO}_{3}^{-}$that allows PNM formation (Karl et al., 2008). Removal pathways for $\mathrm{NO}_{2}^{-}$in aerobic environments include oxidation by nitrite-oxidizing bacteria and phytoplankton uptake. The unexplained accumulation of $\mathrm{NO}_{2}^{-}$leaves fundamental questions unanswered about what limits primary productivity, nitrogen remineralization, or both, in the lower euphotic zone.

Direct measurements of $\mathrm{NO}_{3}^{-}$assimilation into phytoplankton (Dugdale and Goering, 1967), nitrate reductase enzyme activity (Eppley et al., 1969), and more recent nucleic acid-based methods for detecting nitrate reductase-encoding genes (Jenkins et al., 2006; Paerl et al., 2008; Ward, 2008) and gene transcripts (Paerl et al., 2012) have all shown the importance and prevalence of nitrate-reducing activity in marine phytoplankton and the potential for $\mathrm{NO}_{2}^{-}$production. None of these methods, however, address how much $\mathrm{NO}_{2}^{-}$ is released into the water column, where it is detected in the dissolved phase, versus how much remains in the cell. High-sensitivity, high-precision techniques now allow access to stable isotope ratios of both nitrogen and oxygen in $\mathrm{NO}_{2}^{-}$ $\left(\delta^{15} \mathrm{~N}_{\mathrm{NO}_{2}}\right.$ and $\delta^{18} \mathrm{O}_{\mathrm{NO}_{2}}$ ) (McIlvin and Altabet, 2005; Casciotti and McIlvin, 2007). These new methods enable the use of natural abundance stable isotopes to trace the mechanisms of $\mathrm{NO}_{2}^{-}$production and consumption pathways, although uncertainties remain (Buchwald and Casciotti, 2010, 2013; Casciotti et al., 2010; Buchwald et al., 2012).

It has been recognized for some time that $\mathrm{AOB}$ are present at the depth of the PNM (Olson, 1981a; Ward et al., 1982). More recently, marine AOA abundance and AOA : AOB ratios have been correlated with $\left[\mathrm{NO}_{2}^{-}\right]$(Murray et al., 1999; Beman et al., 2010). Archaeal genes for ammonia oxidation (ammonia monooxygenase subunit $\mathrm{A}, a m o A$ ) have also been found in and around the PNM (Beman et al., 2010; Santoro et al., 2010; Newell et al., 2011). The photosynthetic community present near the PNM, at approximately the $1 \%$ light depth, is composed predominantly of low-light Prochlorococcus ecotypes (Rocap et al., 2003) and picoeukaryotes. Both of these groups have been recently implicated in active $\mathrm{NO}_{3}^{-}$utilization and thus are a potential source of $\mathrm{NO}_{2}^{-}$in the PNM. Metagenomic data (Martiny et al., 2009), flow cytometry coupled with stable isotope tracers (Casey et al., 2007), and natural abundance stable isotope measurements (Fawcett et al., 2011) suggest that some Prochlorococcus ecotypes are capable of using both $\mathrm{NO}_{3}$ and $\mathrm{NO}_{2}$. Picoeukaryotes also appear to actively assimilate nitrate (Fawcett et al., 2011) and can grow at rapid rates in low-nitrogen open-ocean environments (Cuvelier et al., 2010).

The purpose of this study was to determine the pathways of $\mathrm{NO}_{2}^{-}$formation in the PNM of the eastern North Pacific Ocean by coupling high-precision, low-level measurements of $\mathrm{NO}_{2}^{-}$and ammonium $\left(\mathrm{NH}_{4}^{+}\right)$concentrations with ${ }^{15} \mathrm{~N}$ tracer experiments and enumeration of microbial groups. Ammonia oxidation (production of $\mathrm{NO}_{2}^{-}$and $\mathrm{NO}_{2}^{-}+\mathrm{NO}_{3}^{-}$ from $\mathrm{NH}_{3}$ ) and $\mathrm{NO}_{3}^{-}$reduction to $\mathrm{NO}_{2}^{-}$were measured, as was abundance of potentially $\mathrm{NO}_{2}^{-}$-producing organisms in and around the PNM (photosynthetic eukaryotes, Synechococcus, and Prochlorococcus, AOB, and AOA). These measurements allow a direct comparison of $\mathrm{NO}_{2}^{-}$production from $\mathrm{NO}_{3}^{-}$and from $\mathrm{NH}_{4}^{+}$in and around the $\mathrm{PNM}$ in concert with quantification of relevant organisms, and precise $\mathrm{NH}_{4}^{+}$ and $\mathrm{NO}_{2}^{-}$concentration measurements across a gradient in primary productivity.

\section{Materials and methods}

\subsection{Study site and sample collection}

Samples were collected 1-12 October 2009 during cruise WFAD09 aboard the R/V Western Flyer. The cruise track was an $\sim 800 \mathrm{~km}$ transect extending from Moss Landing, California, USA, along California Cooperative Oceanic Fisheries Investigations (CalCOFI) Line 67. The transect extended across the central California Current (Collins et al., $2003)$ to station $67.155\left(33.27^{\circ} \mathrm{N}, 129.43^{\circ} \mathrm{W}\right)$. Fifteen stations were sampled for nutrients, chlorophyll $a$, and flow cytometry, while two stations $\left(67.70,36.13^{\circ} \mathrm{N}, 123.49^{\circ} \mathrm{W}\right.$; and 67.155 , Fig. 1a) were chosen for further microbial characterization and geochemical rate measurements.

Water samples were collected at discrete depths between 0 and $1000 \mathrm{~m}$ using a 12-bottle rosette sampler. The sampler was equipped with an SBE 9 (Sea-Bird Electronics) to measure conductivity, temperature, and pressure as well as an in situ ultraviolet spectrophotometer (ISUS; Johnson and Coletti, 2002) for real-time $\mathrm{NO}_{3}^{-}$concentration profiling. Samples for standard nutrient analyses were collected in $27 \mathrm{~mL}$ HDPE scintillation vials and stored frozen until analysis (Sakamoto et al., 1990). Samples for onboard lowlevel nutrient analyses (described below) were collected in 60 or $125 \mathrm{~mL}$ polyethylene bottles that had been initially 

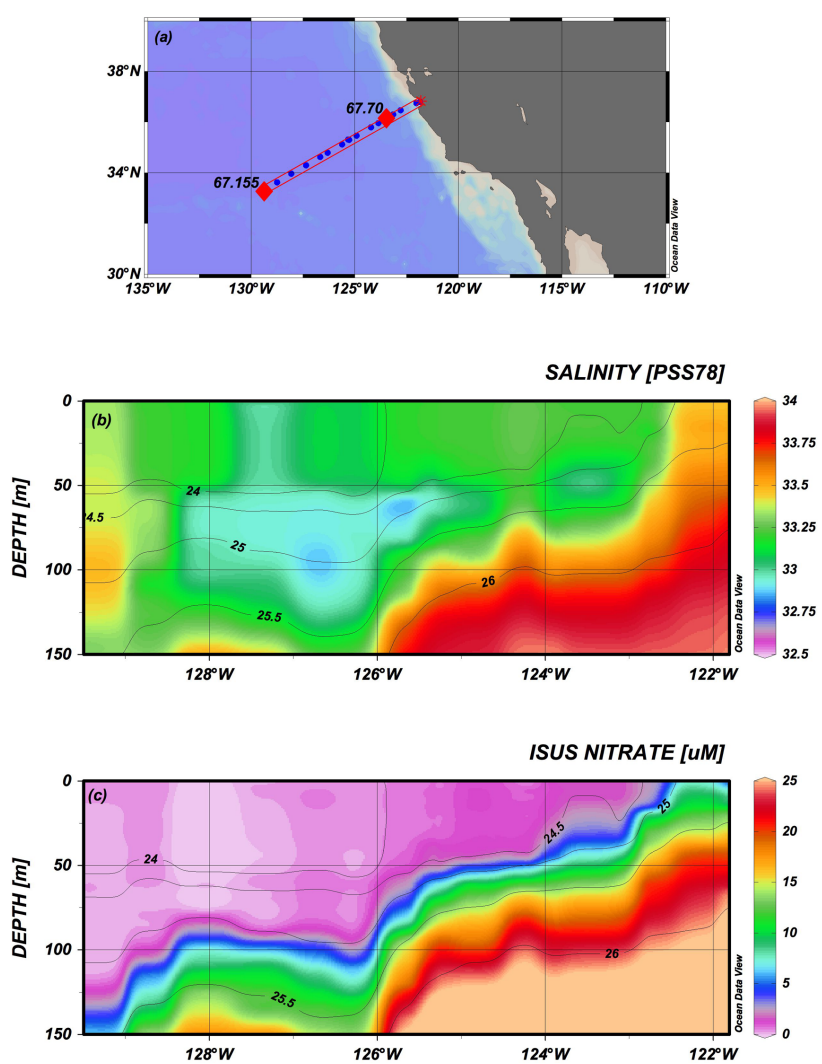
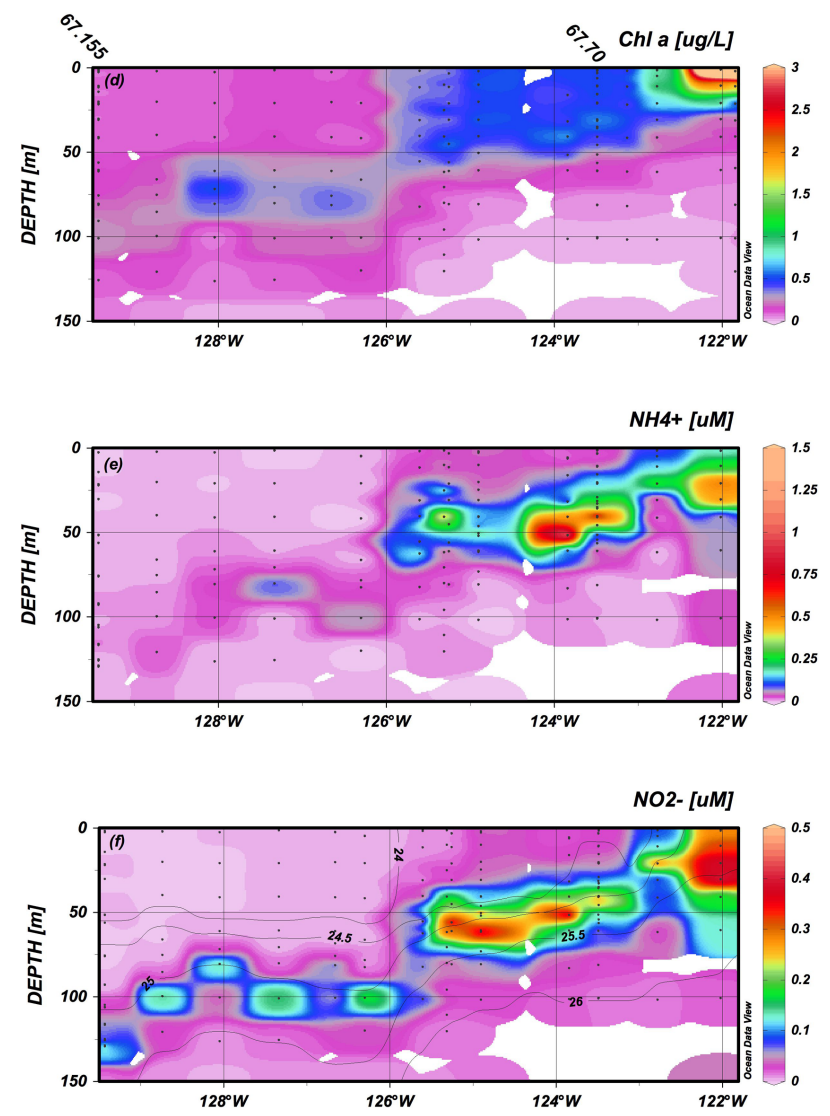

Fig. 1. Longitudinal sections along (a) CalCOFI Line 67 in the eastern North Pacific Ocean, September 2009, of (b) salinity, (c) nitrate ([NO $\left.\mathrm{NO}_{3}^{-}\right]$) from an in situ ultraviolet spectrophotometer (ISUS), (d) $\mathrm{Chl} a\left(\mu \mathrm{g} \mathrm{L}^{-1}\right)$ extracted from $\mathrm{GF} / \mathrm{F}$ filters, (e) ammonium (NH$\left.)^{+}\right)$, and (f) nitrite $\left(\mathrm{NO}_{2}^{-}\right)$. Data are shown from the westbound transect. Isopycnal surfaces (potential density anomaly, sigma theta) are overlaid as black contour lines in panels (b), (c), and (f). Sections made in Ocean Data View version 4.5.1 (http://odv.awi.de) using the VG gridding algorithm.

cleaned in Micro-90 cleaning solution (Andwin Scientific) and subsequently acid-washed in $1.2 \mathrm{~N} \mathrm{HCl}$. Phytoplankton samples for shore-based flow cytometry were collected from the rosette in $60 \mathrm{~mL}$ amber HDPE bottles, then transferred to triplicate $1 \mathrm{~mL}$ cryovials (Nunc) and preserved with $0.25 \%$ (final concentration) TEM grade glutaraldehyde (Tousimis) and fixed in the dark at room temperature for 20 min before flash-freezing in liquid nitrogen. Samples for nucleic acid extraction were collected from the rosette in polycarbonate bottles. Cells were harvested by pressure filtration of $1-2 \mathrm{~L}$ of seawater onto $25 \mathrm{~mm}$-diameter, $0.2 \mu \mathrm{m}$ pore-size polyethersulfone membrane filters (Pall Supor 200) housed in Swinnex filter holders (Millipore) using a peristaltic pump (Cole Parmer Masterflex) and silicone tubing. Filters were flashfrozen in $2 \mathrm{~mL}$ gasketed bead-beating tubes (Fisher Scientific) using liquid nitrogen.

\subsection{Low-level nutrient analyses}

Measurements of low concentrations $(<1 \mu \mathrm{M})$ of $\mathrm{NH}_{4}^{+}$, $\mathrm{NO}_{2}^{-}$, and $\mathrm{NO}_{3}^{-}$were made onboard the ship as soon as pos- sible after collection. Higher-resolution (12 depths in the upper $200 \mathrm{~m}$ ) nutrient measurements were made on the rosette cast immediately preceding the cast for incubation water collection. Nutrient measurements were also made at the incubation depths for rate determinations (see below). The $\mathrm{NH}_{4}^{+}$analyzer was based on the method described in Plant et al. (2009) but used a sequential injection platform. $\left[\mathrm{NO}_{2}^{-}\right]$ and $\left[\mathrm{NO}_{3}^{-}\right]$were measured using standard colorimetric methods coupled with liquid waveguide capillary cells (LWCC) for detection (Zhang, 2000; Patey et al., 2008). The LWCC is composed of quartz capillary tubing $(550 \mu \mathrm{m}$ inner diameter) covered by an outer surface cladding of AF-2400 Teflon resulting in a refractive index of 1.29 (World Precision Instruments). This refractive index is smaller than seawater (1.34) so that light is internally reflected through the water-filled waveguide to achieve path lengths of $1 \mathrm{~m}$ (for $\left[\mathrm{NO}_{3}^{-}\right]$determination) and $2 \mathrm{~m}$ (for $\left[\mathrm{NO}_{2}^{-}\right]$determination). The chemistry ( $\mathrm{Cd}$ reduction, followed by azo dye formation) and sample processing manifold used for the low-level $\mathrm{NO}_{3}^{-}$and $\mathrm{NO}_{2}^{-}$analyses were based on the rapid flow an- 
alyzer described in Sakamoto et al. (1990). Based on 3x the standard deviation of low nutrient blanks, the low-level $\mathrm{NH}_{4}^{+}, \mathrm{NO}_{2}^{-}$, and $\mathrm{NO}_{3}^{-}$measurements had detection limits of $10 \mathrm{nmol} \mathrm{L}^{-1}, 2 \mathrm{nmol} \mathrm{L}^{-1}$, and $4 \mathrm{nmol} \mathrm{L}^{-1}$, respectively. Correlations among low-level nutrient concentrations and between nutrients and organism abundance were evaluated using Spearman non-parametric rank correlations implemented in MATLAB R2011b (Mathworks).

\subsection{Chlorophyll $a$ determination and flow cytometry}

Chl $a$ was measured by fluorescence determination on a Turner 10-005R fluorometer. Samples were vacuum-filtered onto $25 \mathrm{~mm}$ glass fiber filters $(\mathrm{GF} / \mathrm{F})$ and extracted for $24 \mathrm{~h}$ in $90 \%$ acetone (Venrick and Hayward, 1984).

Fixed cell samples were analyzed on a flow cytometer equipped with a $200 \mathrm{~mW} 488 \mathrm{nM}$ laser (InFlux, Becton Dickson). Autoclaved, $0.1 \mu \mathrm{m}$ filtered $1 \mathrm{x}$ phosphate-buffered saline was used as sheath fluid. Fixed samples were thawed in a water bath in the dark, and fluorescent polystyrene beads $(0.75 \mu \mathrm{m}$, Polysciences, Inc.) added, immediately prior to each run. Each sample was run for 2 min prior to data collection, and data were subsequently collected for $10 \mathrm{~min}$ at a flow rate of approximately $25 \mu \mathrm{L} \mathrm{min}^{-1}$, measured by an inline flow meter (Sensirion SLG-1430 run with software designed by J. Swalwell, University of Washington). Sheath and sample pressure were adjusted as needed to maintain constant flow rate, to approximately 18.5 and $19.2 \mathrm{psi}$, respectively. Forward-angle light scatter (FALS), pulse width, side scatter $\left(90^{\circ}\right.$ angle; SSC), red $(692 \pm 40 \mathrm{~nm}$ band-pass filter) and orange (527 $\pm 27 \mathrm{~nm}$ band-pass filter) autofluorescence were recorded. Listmode files were analyzed in Winlist 6.0 (Verity Software House) to enumerate Prochlorococcus, Synechococcus, and small eukaryote populations that were defined based on natural autofluorescence and FALS characteristics.

While fixed samples were used for most analyses herein, unfixed samples were used to analyze oligotrophic surface Prochlorococcus populations (while at sea) that are better resolved when run live, and to verify that eukaryotic populations remained intact (numerically correct) with fixation and cryogenic storage. Live samples were run similarly to fixed samples, with slight modifications to accommodate the effect of the ship's motion. Specifically, because the ship's motion caused considerable movement of sheath fluid, the flow rate ranged from 12 to $30 \mu \mathrm{L} \mathrm{min}^{-1}$ in a time period of seconds. To minimize this effect, the instrument was run with at least $5 \mathrm{~L}$ of sheath fluid at all times and total event rates only recorded when the flow rate was $25 \mu \mathrm{L} \mathrm{min}^{-1}$ (the average rate for all runs). Flow rate and cell count comparisons of samples run live and fixed showed that sheath pressure variability did not lower accuracy (data not shown).

\subsection{Ammonia oxidation and nitrate reduction rate incubations}

Rate measurements were conducted using stable isotope tracer additions $\left({ }^{15} \mathrm{~N}\right)$ for five depths at stations 67.70 and 67.155 targeting the middle of the euphotic zone, just above the PNM, at the PNM, just below the PNM, and a depth well below the photic zone $(500 \mathrm{~m})$. For each depth, six $500 \mathrm{~mL}$ bottle incubations were conducted: two ammonia oxidation rate bottles (with ${ }^{15} \mathrm{NH}_{4}^{+}$added), two $\mathrm{NO}_{3}^{-}$reduction rate bottles (with ${ }^{15} \mathrm{NO}_{3}^{-}$added), and two filtered control bottles (one with ${ }^{15} \mathrm{NH}_{4}^{+}$and one with ${ }^{15} \mathrm{NO}_{3}^{-}$). Water for the experimental bottles was collected directly from the rosette into $500 \mathrm{~mL}$ acid-cleaned polycarbonate bottles. Water for filtered controls was then $0.2 \mu \mathrm{m}$-pressure filtered into fresh acid-clean bottles. Each bottle was spiked with $100 \mu \mathrm{L}$ of $1 \mathrm{mmol} \mathrm{L}^{-1}{ }^{15} \mathrm{~N}$-labeled substrate $\left({ }^{15} \mathrm{NH}_{4}^{+}\right.$or ${ }^{15} \mathrm{NO}_{3}^{-}, 99.5$ atom percent ${ }^{15} \mathrm{~N}$; equivalent to a final label concentration of $200 \mathrm{nmol} \mathrm{L}-1{ }^{15} \mathrm{~N}$; Cambridge Isotope Laboratories). ${ }^{15} \mathrm{NO}_{3}^{-}$addition treatments from the $500 \mathrm{~m}$ depth at each station were instead spiked with $200 \mu \mathrm{L}$ of ${ }^{15} \mathrm{NO}_{3}^{-}$to achieve a final label concentration of $400 \mathrm{nM}$. These ${ }^{15} \mathrm{~N}$ additions corresponded to $0.5-13 \mathrm{x}$ ambient $\mathrm{NH}_{4}^{+}$and $0.02-0.23 \mathrm{x}$ ambient $\mathrm{NO}_{3}^{-}$(see below). Bottles were incubated in an on-deck circulating seawater incubator in neutral density-screened bags calibrated to approximate the in situ light field at each depth using a photosynthetically active radiation sensor (Biospherical Instruments QSL-2200). Replicate $50 \mathrm{~mL}$ samples were removed from each bottle at 4 time points $(0,12,24$, and $36 \mathrm{~h}$ ) for onboard determination of $\left[\mathrm{NH}_{4}^{+}\right],\left[\mathrm{NO}_{2}^{-}\right]$, and $\left[\mathrm{NO}_{2}^{-}+\mathrm{NO}_{3}^{-}\right]$as described above (unfiltered), shore-based determinations of $\left[\mathrm{NO}_{2}^{-}+\mathrm{NO}_{3}^{-}\right]$and $\left[\mathrm{PO}_{4}^{3-}\right]$ (unfiltered, frozen), and $\delta^{15} \mathrm{~N}_{\mathrm{NO}_{2}}$ and $\delta^{15} \mathrm{~N}_{\mathrm{NO}_{\mathrm{x}}}(0.2 \mu \mathrm{m}$ syringe-filtered, frozen), as described below.

\subsection{Stable isotope analyses}

Analyses of $\delta^{15} \mathrm{~N}$ of $\mathrm{NO}_{2}^{-}$and $\mathrm{NO}_{x}\left(\mathrm{NO}_{2}^{-}+\mathrm{NO}_{3}^{-}\right)$in time course samples from the incubations were performed with a Thermo-Finnigan Delta ${ }^{\text {PLUS }}$ XP isotope ratio mass spectrometer outfitted with a custom purge-and-trap system. Samples were prepared from $5 \mathrm{nmol}$ or $10 \mathrm{nmol}$ of analyte using the azide (McIlvin and Altabet, 2005) and denitrifier methods (Sigman et al., 2001; McIlvin and Casciotti, 2011) for $\delta^{15} \mathrm{~N}_{\mathrm{NO}_{2}}$ and $\delta^{15} \mathrm{~N}_{\mathrm{NO}_{\mathrm{x}}}$ determination, respectively. $\delta^{15} \mathrm{~N}_{\mathrm{NO}_{2}}$ values were calibrated against nitrite isotope reference materials $\mathrm{N}-23, \mathrm{~N}-7373$, and $\mathrm{N}-10219$ (Casciotti and McIlvin, 2007) analyzed in parallel. $\delta^{15} \mathrm{~N}_{\mathrm{NO}_{\mathrm{x}}}$ values were calibrated against $\mathrm{NO}_{3}^{-}$isotope reference materials USGS 32, USGS 34, and USGS 35, analyzed in parallel. Duplicate $\delta^{15} \mathrm{~N}_{\mathrm{NO}_{2}}$ analyses were performed on each sample, while $\delta^{15} \mathrm{~N}_{\mathrm{NO}_{\mathrm{x}}}$ measurements were performed once. Due to the necessary addition of carrier $\mathrm{NO}_{2}^{-}$(see below), the $\delta^{15} \mathrm{~N}_{\mathrm{NO}_{2}}$ analyses had mean standard deviations (for repli- 
Table 1. Stable isotope tracer additions and corresponding laboratory analysis methods used in bottle incubations for geochemical rate determination.

\begin{tabular}{|c|c|c|c|}
\hline Rate determination & $\begin{array}{l}{ }^{15} \mathrm{~N} \text { addition } \\
\text { (substrate "pool") }\end{array}$ & $\begin{array}{l}{ }^{15} \mathrm{~N} \text { product } \\
\text { (product "pool") }\end{array}$ & Analysis \\
\hline $\begin{array}{l}\text { Ammonia oxidation to } \mathrm{NO}_{\mathrm{x}}^{-} \\
\text {Ammonia oxidation to } \mathrm{NO}_{2}^{-} \\
\text {Nitrate reduction }\end{array}$ & $\begin{array}{l}{ }^{15} \mathrm{NH}_{4}^{+} \\
{ }^{15} \mathrm{NH}_{4}^{+} \\
{ }^{15} \mathrm{NO}_{3}^{-}\end{array}$ & $\begin{array}{l}\mathrm{NO}_{2}^{-}+\mathrm{NO}_{3}^{-} \\
\mathrm{NO}_{2}^{-} \\
\mathrm{NO}_{2}^{-}\end{array}$ & $\begin{array}{l}\delta^{15} \mathrm{~N}_{\mathrm{NO}_{2}}+\mathrm{NO}_{3} \text {, denitrifier method } \\
\delta^{15} \mathrm{NO}_{2}^{-} \text {, azide method } \\
\delta^{15} \mathrm{NO}_{2}^{-} \text {, azide method }\end{array}$ \\
\hline
\end{tabular}

cate samples) ranging from $0.3 \%$ to $1.1 \%$. Precision of $\delta^{15} \mathrm{~N}_{\mathrm{NO}_{3}}$ analysis using the denitrifier method is $0.5 \%$ or better (McIlvin and Casciotti, 2011).

Handling of all ${ }^{15} \mathrm{~N}$-enriched samples was carried out in a laboratory dedicated to this purpose. $\left[\mathrm{NO}_{2}^{-}\right]$in all incubation samples was too low $\left(<1 \mu \mathrm{mol} \mathrm{L}{ }^{-1}\right)$ to allow direct $\delta^{15} \mathrm{~N}_{\mathrm{NO}_{2}}$ measurements. Therefore, either 5 or $10 \mathrm{nmol}$ of $\mathrm{NO}_{2}^{-}$with known natural abundance isotopic composition was added (either reference material $\mathrm{N}-23, \delta \delta^{15} \mathrm{~N}_{\mathrm{NO}_{2}}=-3.7 \%$, or a laboratory $\mathrm{NO}_{2}^{-}$stock, $\delta^{15} \mathrm{~N}_{\mathrm{NO}_{2}}=1.1 \%$ ) to $5 \mathrm{~mL}$ of each incubation sample prior to preparation and analysis. To prevent potential ${ }^{15} \mathrm{NO}_{3}^{-}$contamination of the laboratory and the mass spectrometer purge-and-trap system, $1 \mu \mathrm{mol}$ of natural abundance $\mathrm{NO}_{3}^{-}$was also added to each incubation sample that had been incubated with ${ }^{15} \mathrm{NO}_{3}^{-}$prior to $\delta^{15} \mathrm{~N}_{\mathrm{NO}_{2}}$ analysis. There was no interference of the $\mathrm{NO}_{3}^{-}$addition on $\delta^{15} \mathrm{~N}_{\mathrm{NO}_{2}}$ determination of reference materials, as demonstrated previously (Casciotti and McIlvin, 2007). The isotope ratio of the original sample was then calculated by subtracting the concentration-weighted isotope ratio of the standard addition.

\subsection{Rate calculations}

To calculate rates of $\mathrm{NH}_{3}$ oxidation and $\mathrm{NO}_{3}^{-}$reduction, we modeled the ${ }^{15} \mathrm{~N}$ and ${ }^{14} \mathrm{~N}$ contents of the receiving "product" pool (Table 1) as a box, with inputs from the labeled "substrate" pool and outputs through $\mathrm{NO}_{\mathrm{x}}$ or $\mathrm{NO}_{2}^{-}$removal using Eq. (1):

$$
\frac{{ }^{15} \mathrm{~N}_{\mathrm{NO}_{\mathrm{x}}}}{{ }^{14} \mathrm{~N}_{\mathrm{NO}_{\mathrm{x}}}}(t)=\frac{{ }^{15} \mathrm{~N}_{0} e^{\frac{-k t}{\alpha}}+\frac{F_{\mathrm{in}} a t_{\text {in }}}{k / \alpha}\left(1-e^{\frac{-k t}{\alpha}}\right)}{{ }^{14} \mathrm{~N}_{0} e^{-k t}+\frac{F_{\mathrm{in}}\left(1-a t_{\mathrm{in}}\right)}{k}\left(1-e^{-k t}\right)},
$$

where ${ }^{15} N_{\mathrm{NO}_{\mathrm{x}}} /{ }^{14} \mathrm{~N}_{\mathrm{NO}_{\mathrm{x}}}(t)$ is the ${ }^{15} \mathrm{~N} /{ }^{14} \mathrm{~N}$ ratio in the product pool at any time $t,{ }^{15} N_{0}$ and ${ }^{14} N_{0}$ are the initial ${ }^{15} \mathrm{~N}$ and ${ }^{14} \mathrm{~N}$ concentrations in the product pool, $a t_{\text {in }}$ is the initial atom fraction of ${ }^{15} \mathrm{~N}$ in the substrate pool, and $k$ is the removal rate constant for $\mathrm{NO}_{2}^{-}$or $\mathrm{NO}_{\mathrm{x}}^{-}$removal (with units $\mathrm{h}^{-1}$ ). For example, to calculate $\mathrm{NO}_{3}^{-}$reduction rates, where $\mathrm{NO}_{3}^{-}$is the substrate and $\mathrm{NO}_{2}^{-}$is the product, the left-hand side of the equation represents the time course change in ${ }^{15} N_{\mathrm{NO}_{2}} /{ }^{14} N_{\mathrm{NO}_{2}}$ in incubations with added ${ }^{15} \mathrm{NO}_{3}^{-}$and $a t_{\text {in }}$ refers to the initial atom fraction ${ }^{15} \mathrm{NO}_{3}^{-}$. This approach has been described in detail previously (Santoro et al., 2010). $a t_{\text {in }}$ was calculated by mass balance from the ambient nutrient concentrations and the ${ }^{15} \mathrm{~N}$ tracer addition. Initial atom fraction ${ }^{15} \mathrm{~N}$ in the $\mathrm{NH}_{4}^{+}$additions ranged from 0.35 to 0.93 . Initial atom fraction ${ }^{15} \mathrm{~N}$ in the $\mathrm{NO}_{3}^{-}$additions ranged from 0.02 to 0.19 . Coefficients $F_{\text {in }}$ (the rate of $\mathrm{NO}_{2}^{-}$or $\mathrm{NO}_{\mathrm{x}}^{-}$production, with units $\mu \mathrm{mol} \mathrm{L}^{-1} \mathrm{~h}^{-1}$ ) and $k$ were calculated using a non-linear least-squares curve-fitting routine, implemented in MATLAB R2011b with the Optimization Toolbox; results were then converted to units of $n m o l L^{-1} \mathrm{~d}^{-1}$. Standard error in the fit coefficients was calculated by approximating the covariance matrix, and using the square root of the diagonal to calculate the standard error.

Our model does not prescribe a specific biogeochemical process for the $\mathrm{NO}_{2}^{-}$or $\mathrm{NO}_{\mathrm{x}}^{-}$removal term; this removal process may be nitrite oxidation or assimilation. Fractionation factors $(\alpha)$ for $\mathrm{NO}_{2}^{-}$or $\mathrm{NO}_{\mathrm{x}}^{-}$removal were approximated using values for $\mathrm{NO}_{2}^{-}$and $\mathrm{NO}_{\mathrm{x}}^{-}$assimilation, 1.001 and 1.005, respectively. At the levels of ${ }^{15} \mathrm{~N}$ enrichment used here, the model is not sensitive to changes in this parameter (and therefore the uptake mechanism) over a range of reasonable values (0.995-1.010, data not shown). Removal rates $\left(\mathrm{nmol} \mathrm{L}{ }^{-1} \mathrm{~d}^{-1}\right)$ were calculated as $k$ (converted to units of $\mathrm{d}^{-1}$ ) multiplied by the initial $\left[\mathrm{NO}_{2}^{-}\right]$.

The detection limit for each rate measurement is dependent on the initial atom fraction ${ }^{15} \mathrm{~N}$ enrichment in the substrate pool and the concentration of the product pool. High initial atom fraction enrichment in the substrate pool and low concentrations in the product pool will result in greater sensitivity. The theoretical detection limit, a rate which we can be reasonably certain is significantly different than zero, was calculated individually for each rate and depth as the $\mathrm{NO}_{2}^{-}$production rate necessary to cause a $2 \%$ increase in $\delta^{15} \mathrm{~N}_{\mathrm{NO}_{2}}$ from the initial value (including the carrier), i.e., twice the precision of the measurement. Detection limits for ammonia oxidation at the mesotrophic station (67.70) ranged from $0.3 \mathrm{nmol} \mathrm{L}^{-1} \mathrm{~d}^{-1}$ to $1.7 \mathrm{nmol} \mathrm{L}^{-1} \mathrm{~d}^{-1}$ at $33 \mathrm{~m}$, and it was $0.5 \mathrm{nmol} \mathrm{L}^{-1}$ at the PNM. At the oligotrophic station (67.155), ammonia oxidation rate detection limits ranged from $0.02 \mathrm{nmol} \mathrm{L}^{-1} \mathrm{~d}^{-1}$ at $110 \mathrm{~m}$ to $0.86 \mathrm{nmol} \mathrm{L}^{-1} \mathrm{~d}^{-1}$ in the PNM. Rate determinations of $\mathrm{NO}_{2}^{-}$production from $\mathrm{NO}_{3}^{-}$ were generally less sensitive than ammonia oxidation rates, due to lower ${ }^{15} \mathrm{~N}$ enrichments in the $\mathrm{NO}_{3}^{-}$pool, with detection limits at 67.70 ranging from $0.1 \mathrm{nmol} \mathrm{L}^{-1} \mathrm{~d}^{-1}$ at 
$55 \mathrm{~m}$ to $10.4 \mathrm{nmol} \mathrm{L}^{-1} \mathrm{~d}^{-1}$ within the PNM. At 67.155 , detection limits ranged from $0.01 \mathrm{nmol} \mathrm{L}^{-1} \mathrm{~d}^{-1}$ at $50 \mathrm{~m}$ to $9.8 \mathrm{nmol} \mathrm{L}^{-1} \mathrm{~d}^{-1}$ at $500 \mathrm{~m}$, and it was $4.1 \mathrm{nmol} \mathrm{L}^{-1} \mathrm{~d}^{-1}$ at the PNM.

\subsection{Nucleic acid extraction}

Nucleic acids (DNA) were extracted from frozen filters as described previously (Santoro et al., 2010), with modifications. Briefly, cells on the filters were lysed directly in the beadbeating tubes with sucrose-EDTA lysis buffer and $1 \%$ SDS. Prior to mechanical lysis, filter samples were subject to three freeze-thaw cycles of $5 \mathrm{~min}$ in liquid nitrogen and $5 \mathrm{~min}$ in a $65^{\circ} \mathrm{C}$ water bath. Tubes were then agitated in a FastPrep bead-beating machine (MP Biomedicals) for $1.5 \mathrm{~min}$ at speed 5.5 , and proteinase $\mathrm{K}$ (Invitrogen) was added to a final concentration of $0.5 \mathrm{mg} \mathrm{mL}^{-1}$. Filters were incubated at $55^{\circ} \mathrm{C}$ for approximately $4 \mathrm{~h}$ and the resulting lysates were purified with the DNeasy kit (Qiagen) using a slightly modified protocol (Santoro et al., 2010). The purified DNA was eluted in $200 \mu \mathrm{L}$ of DNase, RNase-free water (Gibco) and quantified using a fluorometer (Qubit and Quanti-T BR reagent, Invitrogen Molecular Probes).

\subsection{Quantitative PCR}

qPCR assays for total archaeal amoA (AOA) and betaproteobacterial amoA (AOB) were carried out in $25 \mu \mathrm{L}$ reactions using SYBR Green chemistry on a StepOnePlus realtime PCR machine (PE Applied Biosystems). Unless noted otherwise below, each reaction contained $12.5 \mu \mathrm{L}$ Failsafe Green Real-Time PCR PreMix E (Epicentre Biotechnologies), $400 \mathrm{nM}$ each primer, 1.25 U Failsafe Real-Time Enzyme Blend (Epicentre Biotechnologies), and ROX passive reference dye at the concentration recommended by the manufacturer. AOA group-specific assays for "shallow" water column ecotype A (WCA) and "deep" water column ecotype B (WCB) (Mosier and Francis, 2011) used TaqMan Environmental Mastermix (Life Technologies) chemistry as described below. Detection limits for all SYBR assays were 10 copies $\mathrm{mL}^{-1}$ or better; detection limit for TaqMan assays was 1 copies $\mathrm{mL}^{-1}$ or better.

All reactions were run in triplicate with a standard curve spanning approximately $10^{1}-10^{5}$ templates, run in duplicate. Plasmids containing cloned inserts of the target gene (TOPO pCR4 vector, Invitrogen) were used as standards as indicated below. Standards were linearized with the restriction enzyme NotI (New England Biolabs), purified (DNeasy, Qiagen), quantified by fluorometry (Quanti-T HS reagent, Invitrogen), and stored at $-80^{\circ} \mathrm{C}$. Fresh standard dilutions were made from frozen stocks for each day of analysis. A minimum of three negative control qPCR reactions to which no DNA template was added were analyzed with every assay. A melting curve analysis was performed after each SYBR qPCR run with plate reads at a temperature increment of $0.3^{\circ} \mathrm{C} . R^{2}$ values for the standard curves (cycle threshold (Ct) vs. $\log _{10}$ copy number) were 0.98 or better for all runs. Efficiency was calculated relative to a theoretical standard curve slope of 3.32 .

The betaproteobacterial amoA qPCR assay used the amoA1F/2R primer set (Rotthauwe et al., 1997) and the following thermal profile: of $94^{\circ} \mathrm{C}$ for $3 \mathrm{~min}$ followed by 35 cycles of $95^{\circ} \mathrm{C}$ for $45 \mathrm{~s}, 56^{\circ} \mathrm{C}$ for $30 \mathrm{~s}, 72^{\circ} \mathrm{C}$ for $50 \mathrm{~s}$, and a plate reading step at $82^{\circ} \mathrm{C}$ for $10 \mathrm{~s}$. The standard used for this assay was a marine Nitrosospira-like amoA gene generated using amoA genes PCR-amplified from Monterey Bay; average qPCR efficiency was $96 \%$. Total archaeal amoA genes were quantified using the primers Arch-amoAF/ArchamoAR (Francis et al., 2005) with an additional $2 \mathrm{mM}$ $\mathrm{MgCl}_{2}$ added to the reaction chemistry described above, and the following thermal profile: $94^{\circ} \mathrm{C}$ for $3 \mathrm{~min}$, followed by 35 cycles of $94^{\circ} \mathrm{C}$ for $30 \mathrm{~s}, 58^{\circ} \mathrm{C}$ for $45 \mathrm{~s}$, and $72^{\circ} \mathrm{C}$ for $50 \mathrm{~s}$, and a plate read at $80^{\circ} \mathrm{C}$ for $10 \mathrm{~s}$. The standard used for this assay was an archaeal amoA gene amplified from the California Current (Santoro and Casciotti, 2011); average qPCR efficiency was $94 \%$. Group-specific amoA assays used the WCA-amoA-F/R and WCB-amoA-F/R primer and probe sets (Mosier and Francis, 2011) and the following thermal profile: $95^{\circ} \mathrm{C}$ for $10 \mathrm{~min}$, followed by 40 cycles of $95^{\circ} \mathrm{C}$ for $30 \mathrm{~s}$ and $55^{\circ} \mathrm{C}$ for $30 \mathrm{~s}$.

\subsection{One-dimensional $\mathrm{NO}_{2}^{-}$modeling}

A one-dimensional, bulk mixed-layer model (Price, Weller, Pinkel (Price et al., 1986); PWP) was used to approximate physical processes in the mixed layer. The present version of the model was implemented in MATLAB using code developed by Glover et al. (2011) and modified by Martz et al. (2009). The PWP model was initially developed to model diurnal heating and wind-driven mixing over a few days. Subsequent work has extended the model to run times from months to years (Archer et al., 1993; Mathieu and Deyoung, 1995; Plueddemann et al., 1995; Babu et al., 2004; Vage et al., 2008).

The model has $1 \mathrm{~m}$ vertical resolution down to $200 \mathrm{~m}$, a time step of $15 \mathrm{~s}$, and a vertical eddy diffusivity of $1.5 \times 10^{-4} \mathrm{~m}^{2} \mathrm{~s}^{-1}$. PWP is forced at the surface using NCEP/NCAR Reanalysis 1 surface flux data (Kalnay et al., 1996). The 4-times-daily data were provided by the National Oceanic and Atmospheric Administration (NOAA) Earth System Research Laboratory (http://www.esrl.noaa. gov/psd/). Upwelling velocities were calculated from 4times-daily wind stress curl, calculated using data from the NOAA Environmental Research Division (ERD) of the Southwest Fisheries Science Center (http://las.pfeg.noaa. gov/thredds/dodsC/Model/FNMOC/). Wind stress curl was calculated by ERD from analyzed fields of sea level pressure from the Fleet Numerical Meteorology and Oceanography Center (http://www.usno.navy.mil/FNMOC). Ekman depth and vertical velocity attenuation were calculated following 
the approach of Signorini et al. (2001). Climate data were extracted for the 2 months prior to the profile date at each station position. The model was initialized with the 12-depth station $\left[\mathrm{NO}_{2}^{-}\right]$profile data and run $48 \mathrm{~h}$ before being reinitialized with the station profile.

\section{Results}

\subsection{Location and magnitude of the PNM along the cruise transect}

The cruise transect traversed productive, high-chlorophyll waters in Monterey Bay (Chl $a=5.2 \mu \mathrm{g} \mathrm{L}^{-1}$ ) to oligotrophic, open-ocean conditions (surface Chl $a<0.1 \mu \mathrm{g} \mathrm{L}-1$, Fig. 1d). As observed in previous occupations of this line, equatorward flow of the California Current causes upward tilting of isopycnal surfaces toward the coast (east) bringing relatively cold, saline, and high- $\mathrm{NO}_{3}^{-}$waters to the surface near the coast (Fig. 1b and c). The low-salinity core of the California Current was west of $126^{\circ} \mathrm{W}$ (Fig. 1b), relatively far offshore. $\mathrm{NO}_{3}^{-}$in the surface waters decreased along the transect from a high of $7 \mu \mathrm{mol} \mathrm{L}^{-1}$ within Monterey Bay down to below detection $\left(<4 \mathrm{nmol} \mathrm{L}^{-1}\right)$ at 67.155. A subsurface deep chlorophyll maximum (DCM) layer became apparent at $126.3^{\circ} \mathrm{W}$.

We observed a PNM at depths below the chlorophyll maximum at all stations. The PNM deepened offshore (Fig. 1f), concurrent with a deepening of the mixed layer and the appearance of the DCM. The magnitude of the PNM also decreased offshore, ranging from $0.53 \mu \mathrm{mol} \mathrm{L} \mathrm{L}^{-1}$ within Monterey Bay (31-40 m depth) to $0.17 \mu \mathrm{mol} \mathrm{L}^{-1}$ offshore (station 67.155 at $128 \mathrm{~m}$ depth). A distinct $\mathrm{NH}_{4}^{+}$maximum was also observed near the base of the euphotic zone, below the DCM but above the PNM (Fig. 1e). The magnitude of the $\mathrm{NH}_{4}^{+}$maximum ranged from $0.51 \mu \mathrm{molL}^{-1}$ near the coast to $0.014 \mu \mathrm{mol} \mathrm{L}^{-1}$ offshore, with a particularly high $\mathrm{NH}_{4}^{+}$ maximum observed during the second occupation of station 67.70 of $1.5 \mu \mathrm{mol} \mathrm{L}^{-1}$. $\mathrm{NH}_{4}^{+}$was below detection limits at all depths at $67-155$. Depth-integrated $(0-200 \mathrm{~m}) \mathrm{NO}_{2}^{-}$ and $\mathrm{NH}_{4}^{+}$were both correlated with depth-integrated $\mathrm{Chl} a$ ( $r=0.86, p<0.01 ; r=0.63, p=0.02$, respectively).

\subsection{Organism distribution in relation to the PNM}

The shift from cool, nutrient-rich waters along the coast to oligotrophic offshore conditions was reflected in the phytoplankton community (Fig. 2). At the coast, Synechococcus and photosynthetic picoeukaryotes were abundant in surface waters, reaching abundances of $8.72 \times 10^{4}$ cells $\mathrm{mL}^{-1}$ and $2.66 \times 10^{4}$ cells $\mathrm{mL}^{-1}$, respectively, within Monterey Bay where Prochlorococcus cells were undetectable. Both Synechococcus and picoeukaryotes were most abundant in surface waters and decreased in abundance with depth. At any one of these stations picoeukaryotes were present deeper in the wa-
Table 2. Abundance of two ecotypes of ammonia-oxidizing archaea: water column A (WCA) and water column B (WCB) based on the abundance of archaeal amoA genes determined by quantitative PCR using ecotype-specific primers and probes (Mosier and Francis, 2011).

\begin{tabular}{rrrr}
\hline & \multicolumn{3}{c}{ amoA copies $\mathrm{mL}^{-1}$} \\
Station & Depth $(\mathrm{m})$ & WCA & WCB \\
\hline 67.70 & 20 & 480 & $<1$ \\
67.70 & 33 & 170 & $<1$ \\
67.70 & 41 & 2870 & $<1$ \\
67.70 & 54.5 & 11750 & 10 \\
67.70 & 500 & $<1$ & 0 \\
& & & \\
67.155 & 50 & $<1$ & $<1$ \\
67.155 & 115 & 1740 & $<1$ \\
67.155 & 128 & 8310 & 1 \\
67.155 & 150 & 5120 & 190 \\
67.155 & 500 & 190 & 5420 \\
\hline
\end{tabular}

ter column than Synechococcus. Synechococcus abundance was correlated with water temperature $(r=0.27, p=0.01)$, but peak abundance was observed in $16^{\circ} \mathrm{C}$ waters.

Offshore, between 125.6 and $126.3^{\circ} \mathrm{W}$, there was a shift in the photosynthetic community coincident with a transition to $\sim 17{ }^{\circ} \mathrm{C}$ waters (Fig. 2 a,b). Prochlorococcus cells became increasingly abundant west of this transition, reaching high abundances within distinct subsurface peaks, with local maxima of $1.53 \times 10^{5}$ to $2.09 \times 10^{5}$ cells $\mathrm{mL}^{-1}$. Prochlorococcus abundance was inversely related to $\left[\mathrm{NO}_{3}^{-}\right](r=-0.83$, $p<0.001)$ and positively related to water temperature $(r=$ $0.68, p<0.001)$. Organisms from all three groups of phytoplankton were generally present at the depth of the PNM (Fig. 3d, h), though with local minima in cell abundance.

amoA genes were quantified to infer the abundance of ammonia-oxidizing organisms at stations 67.70 and 67.155 . Archaeal amoA genes were detectable at both stations at nearly all depths. At 67.70 abundances ranged from 220 amoA copies $\mathrm{mL}^{-1}$ at the surface to a maximum of $1.4 \times 10^{4}$ copies $\mathrm{mL}^{-1}$ at $55 \mathrm{~m}$ depth (Fig. 3b), just below the PNM. At $500 \mathrm{~m}$ depth, there were $3.1 \times 10^{3}$ copies per $\mathrm{mL}^{-1}-$ less abundant than at the base of the euphotic zone, but more abundant than at the surface. At station 67.155, archaeal amoA abundance ranged from undetectable in the shallowest sample $(50 \mathrm{~m})$ to a maximum of $9.5 \times 10^{3}$ copies $\mathrm{mL}^{-1}$ at $128 \mathrm{~m}$ depth, coincident with the PNM (Fig. 3f). The abundance of water column group "A" amoA genotypes, thought to represent a shallow water ecotype (Francis et al., 2005; Hallam et al., 2006; Beman et al., 2008), accounted for $98 \%$ or greater of the archaeal $a m o A$ genes at both stations at all depths except $500 \mathrm{~m}$ at station 67.155 , where they were less than $5 \%$ of the amoA ecotypes (Table 2).

Bacterial amoA gene abundance at 67.70 ranged from below detection limits in the two shallowest samples to 610 


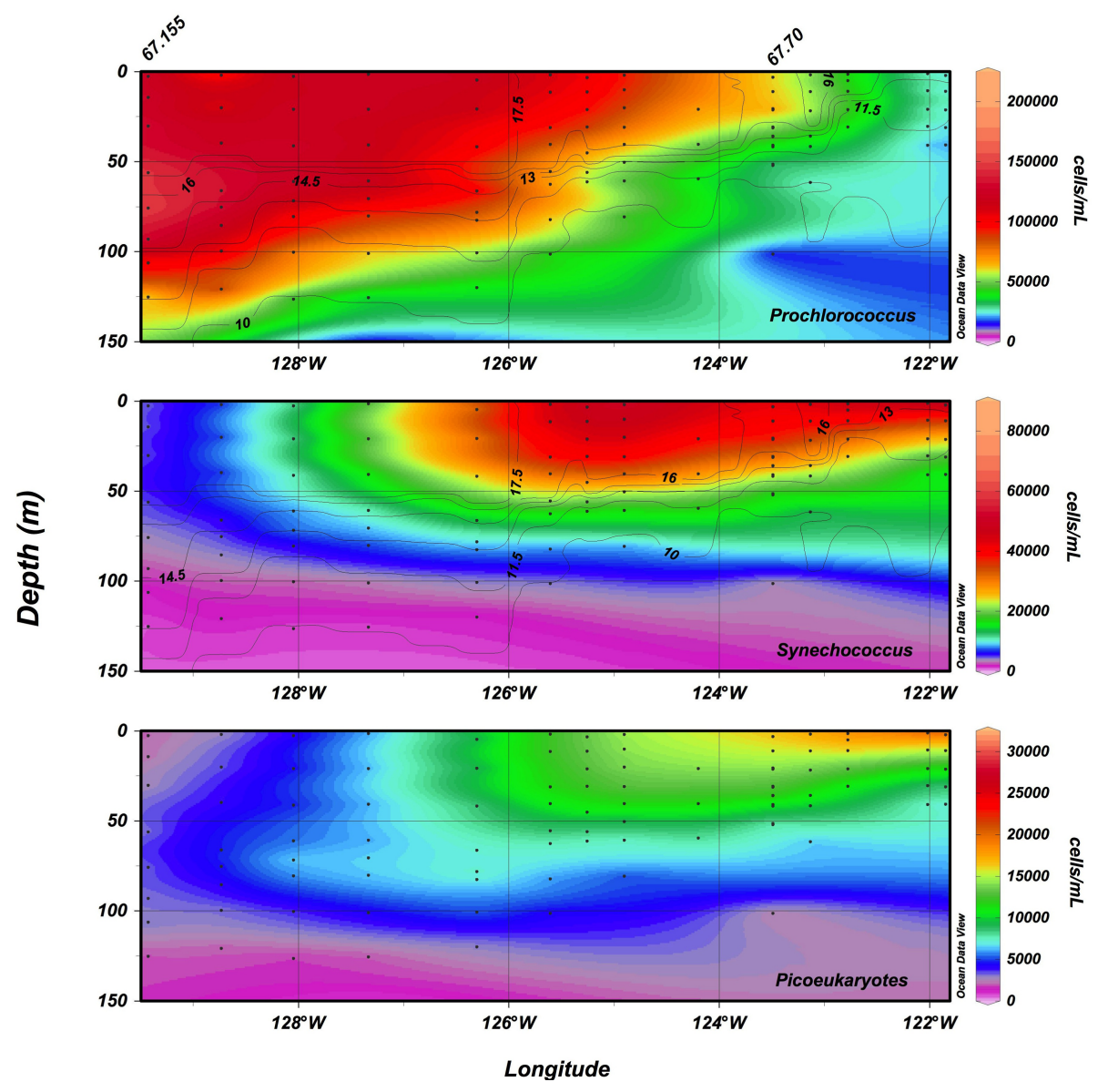

Fig. 2. Abundance of picocyanobacteria and Chl a-containing picoeukaryotes along CalCOFI Line 67. (a) Prochlorococcus, (b) Synechococcus, and (c) picoeukaryotes in cells per mL, as determined by flow cytometry. Contours indicate water temperature in ${ }^{\circ} \mathrm{C}$. Sections made in Ocean Data View version 4.5 (http://odv.awi.de) using the VG gridding algorithm.

copies $\mathrm{mL}^{-1}$ at $55 \mathrm{~m}$, coinciding with the peak in AOA abundance. Bacterial ammonia oxidizers were less abundant at the oligotrophic station, ranging from undetectable at 50, 150, and $500 \mathrm{~m}$, to near the detection limit above the PNM.

\section{3 $\mathrm{NO}_{2}^{-}$production in and around the PNM}

We determined rates of ammonia oxidation $\left(\mathrm{NH}_{3}\right.$ to $\mathrm{NO}_{2}^{-}$ and $\mathrm{NH}_{3}$ to $\mathrm{NO}_{2}^{-}+\mathrm{NO}_{3}^{-}$) at the same stations and depths that we quantified ammonia-oxidizing microbial abundances (Figs. 3, 4). $\left[\mathrm{NO}_{2}^{-}\right]$and $\left[\mathrm{NO}_{3}^{-}\right]$were constant in the incubation bottles during the $36 \mathrm{~h}$ of the incubation, varying only within the error of the measurements (data not shown). $\left[\mathrm{NH}_{4}^{+}\right]$decreased in nearly all incubation bottles, between 30 and $120 \mathrm{nmol} \mathrm{L}^{-1}$ with the greatest decreases in the euphotic zone bottles. Due to the short duration of the cruise we were not able to control the time of day at which the incubations began, but we did not observe any obvious day-night differences in the rate of change in ${ }^{15} \mathrm{~N} /{ }^{14} \mathrm{~N}$ in the product pools (e.g., Fig. 4).
$\mathrm{NO}_{2}^{-}$production from ammonia oxidation in individual bottles at station 67.70 ranged from below detection limits at $500 \mathrm{~m}$ to $31 \pm 13 \mathrm{nmol} \mathrm{L}^{-1} \mathrm{~d}^{-1}$ at $55 \mathrm{~m}$, just below the PNM (Fig. 3a). Combined $\mathrm{NO}_{\mathrm{x}}^{-}$production from ammonia in individual experiments ranged from below the detection limit at the surface and $500 \mathrm{~m}$ to $34 \pm 12 \mathrm{nmol} \mathrm{L}^{-1} \mathrm{~d}^{-1}$ at $55 \mathrm{~m}$. At a given depth, average rates of ammonia oxidation to $\mathrm{NO}_{2}^{-}$and ammonia oxidation to $\mathrm{NO}_{\mathrm{x}}^{-}$were similar, except at $55 \mathrm{~m}$ where the average $\mathrm{NO}_{\mathrm{x}}$ production rate from ammonia $\left(33 \pm 14 \mathrm{nmol} \mathrm{L}^{-1}\right)$ was greater than the average $\mathrm{NO}_{2}^{-}$ production rate $\left(23 \pm 15 \mathrm{nmol} \mathrm{L}^{-1} \mathrm{~d}^{-1}\right)$.

Further offshore at the oligotrophic station (67.155), rates of $\mathrm{NO}_{2}^{-}$production from ammonia oxidation ranged from $0.03 \pm 0.03 \mathrm{nmol} \mathrm{L}^{-1} \mathrm{~d}^{-1}$ at the surface to $9 \pm 22 \mathrm{nmol} \mathrm{L}^{-1} \mathrm{~d}^{-1}$ just below the PNM. The large uncertainties at this depth were due to very low $\left[\mathrm{NO}_{2}^{-}\right]$ (Fig. 3e). Rates of $\mathrm{NO}_{2}^{-}+\mathrm{NO}_{3}^{-}$production showed a similar pattern, ranging from below detection limits at the surface to $8 \pm 5 \mathrm{nmol} \mathrm{L}^{-1} \mathrm{~d}^{-1}$ just below the PNM. 

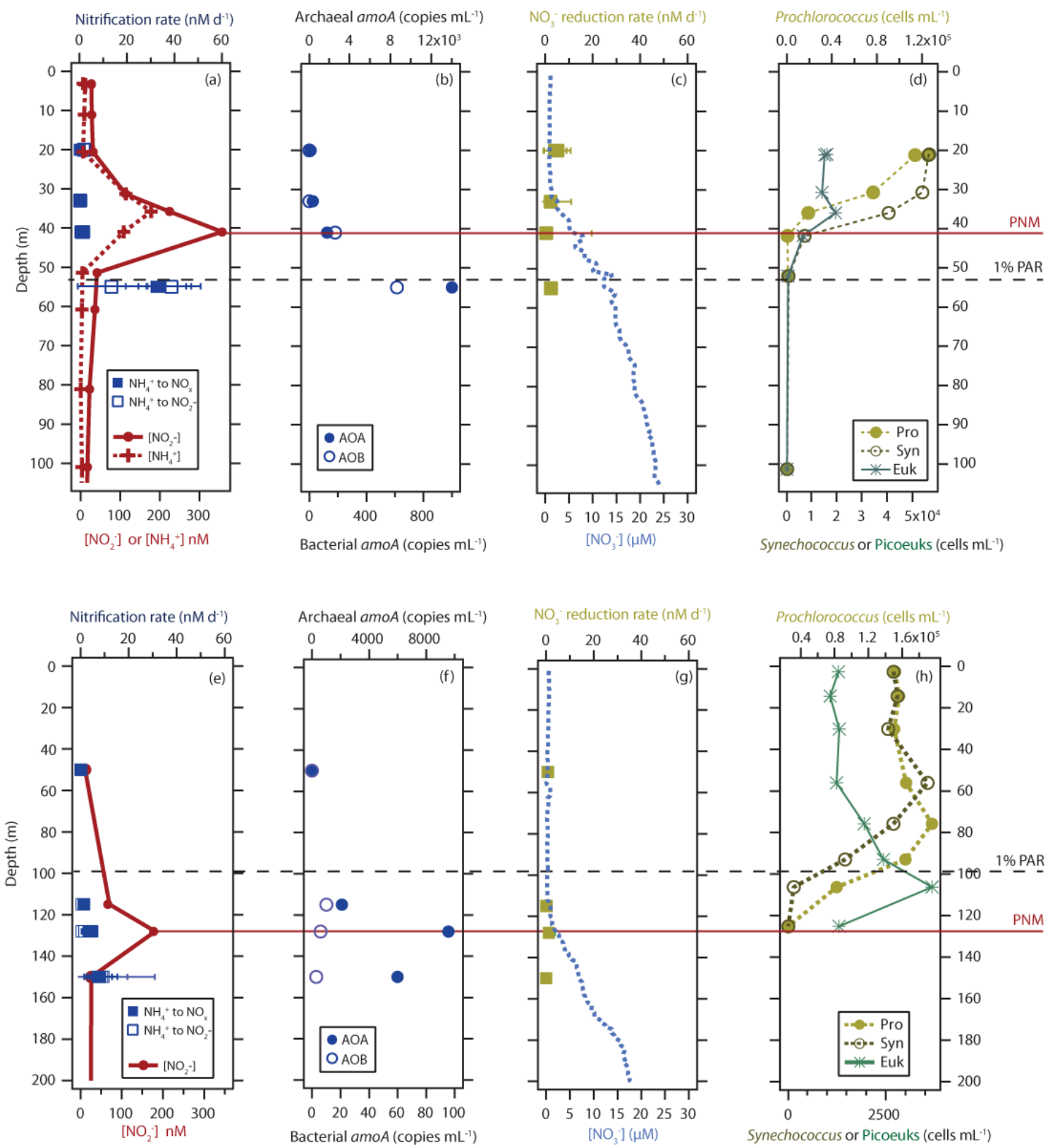

Fig. 3. Depth profiles of dissolved inorganic nitrogen concentrations, $\mathrm{NO}_{2}^{-}$production rates, and microorganism abundance at two stations in the eastern North Pacific. Panels (a-d) station 67.70; panels (e-h) station 67.155. Rate data (panels (a), (c), (e), (g) are shown for replicate bottles, but the two data points overlap at some depths. Error bars indicate standard error in the curve fit for each bottle, and in some cases are smaller than the symbol. Dashed line across all panels indicates the depth of the $1 \%$ light level at the time of water collection. [ $\mathrm{NH}_{4}^{+}$] was below the detection limit at all depths at station 67.155 .

At station 67.70, $\mathrm{NO}_{2}^{-}$production from $\mathrm{NO}_{3}^{-}$was detectable at $20 \mathrm{~m}$, with a mean rate of $4 \pm 5 \mathrm{nmol} \mathrm{L}^{-1} \mathrm{~d}^{-1}$ (Fig. 3c). A similar rate, however, was detected in the filtered control at this depth. $\mathrm{NO}_{2}^{-}$production from $\mathrm{NO}_{3}^{-}$was also detected at $55 \mathrm{~m}$ with a magnitude of $2 \pm 1 \mathrm{nmol} \mathrm{L}^{-1} \mathrm{~d}^{-1}$, just below the PNM and coincident with the highest rates of nitrification. At station 67.155, $\mathrm{NO}_{2}^{-}$production from $\mathrm{NO}_{3}^{-}$above detection limits was only observed at
$50 \mathrm{~m}$, the shallowest depth sampled, at a mean rate of $0.8 \pm 0.3 \mathrm{nmol} \mathrm{L}^{-1} \mathrm{~d}^{-1}$ (Fig. $3 \mathrm{~g}$ ).

The $\left[\mathrm{NO}_{2}^{-}\right]$profiles are the result of both physical and biological processes. If the nutrient profiles are assumed to be in a steady state on the scale of days, and the physical changes can be accounted for, then the residual differences can be attributed to biological activity. Here, a onedimensional mixed-layer model (PWP) was used to simulate 

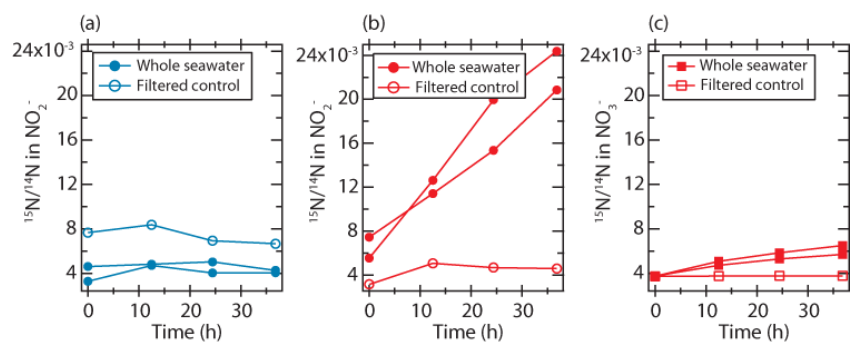

Fig. 4. Representative time course ${ }^{15} \mathrm{~N} /{ }^{14} \mathrm{~N}$ in $\mathrm{NO}_{2}^{-}$and $\mathrm{NO}_{3}^{-}$ from $125 \mathrm{~m}$ incubation at station 67.155 from (a) $\left[{ }^{15} \mathrm{~N}_{3} \mathrm{O}_{3}^{-}\right.$addition, and from (b) and (c) $\left[{ }^{15} \mathrm{~N}\right] \mathrm{H}_{4}^{+}$addition. Values for $\mathrm{NO}_{2}^{-}$(panels a and $\mathbf{b})$ have been corrected for carrier $\mathrm{NO}_{2}^{-}$addition.

the observed distribution of $\left[\mathrm{NO}_{2}^{-}\right]$. At steady state, the rates of $\mathrm{NO}_{2}^{-}$production needed to sustain the peak concentration against the rates of mixing, and the rates of $\mathrm{NO}_{2}^{-}$consumption needed to prevent mixing from broadening the peak, can be computed (Fig. 5). Modeled rates were compared against net $\mathrm{NO}_{2}^{-}$production within the PNM from the incubation experiments. Net $\mathrm{NO}_{2}^{-}$production was calculated as the sum of $\mathrm{NO}_{2}^{-}$production from ammonia oxidation and nitrate reduction, minus $\mathrm{NO}_{2}^{-}$losses, calculated as the $\mathrm{NO}_{2}^{-}$removal rate $(k)$ times the in situ $\left[\mathrm{NO}_{2}^{-}\right]$. At station 67.70 , the model predicts net $\mathrm{NO}_{2}^{-}$production at the PNM of $9.8 \mathrm{mmol} \mathrm{m}^{-2} \mathrm{~d}^{-1}$, greater than aerially integrated measured values $\left(0.5 \mathrm{mmol} \mathrm{m}^{-2} \mathrm{~d}^{-1}\right)$ though there is high uncertainty in the measured value due to uncertainties in the $\mathrm{NO}_{3}^{-}$reduction rate. At station 67.155 , modeled rates of net $\mathrm{NO}_{2}^{-}$production within the PNM were $4.5 \mathrm{mmol} \mathrm{m}^{-2} \mathrm{~d}^{-1}$ and compared well with measured net $\mathrm{NO}_{2}^{-}$production (also $\left.4.5 \mathrm{mmol} \mathrm{m}^{-2} \mathrm{~d}^{-1}\right)$.

\section{Discussion}

$\mathrm{NH}_{4}^{+}$consistently showed a maximum overlying the primary $\mathrm{NO}_{2}^{-}$maximum (Fig. 1e, f). Co-localization of these features has been observed in isolated profiles (Olson, 1981a; Lipschultz et al., 1996; Beman et al., 2012), and across the South Pacific Gyre (Raimbault et al., 2008). The localization of sequential maxima in $\mathrm{Chl} a, \mathrm{NH}_{4}^{+}$, and $\mathrm{NO}_{2}^{-}$strongly suggest that the PNM is a remineralization feature, whereby the sequential products of nitrogen remineralization $-\mathrm{NH}_{4}^{+}$ and $\mathrm{NO}_{2}^{-}-$accumulate one above the other and are correlated in magnitude. A nitrification source of $\mathrm{NO}_{2}^{-}$in the California Current PNM is further supported by the high rates of $\mathrm{NO}_{2}^{-}$production from $\mathrm{NH}_{4}^{+}$relative to production from $\mathrm{NO}_{3}^{-}$. The maximum rates of $\mathrm{NO}_{2}^{-}$production from $\mathrm{NH}_{4}^{+}$, however, were measured below and not within the peak of the PNM, consistent with previous reports from the North Pacific (Dore and Karl, 1996a). This rate distribution has previously led to the proposal that reduction of $\mathrm{NO}_{3}^{-}$by phytoplankton

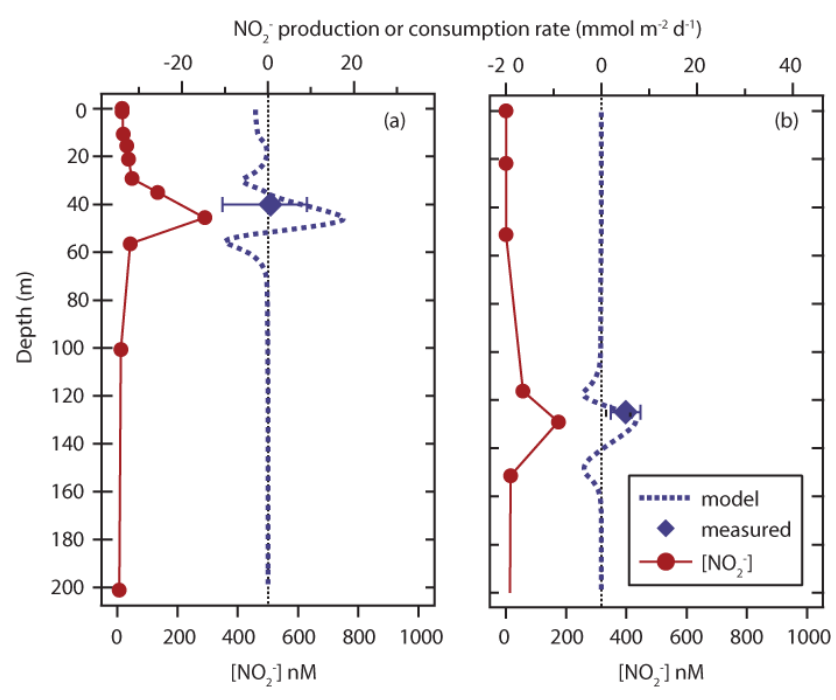

Fig. 5. Vertical profiles of $\mathrm{NO}_{2}^{-}$production and loss rates inferred from a 1-D model (blue dashed line) of observed $\left[\mathrm{NO}_{2}^{-}\right]$profiles (red circles) at (a) station 67.70 and (b) station 67.155. Measured rates of net $\mathrm{NO}_{2}^{-}$production or loss at the PNM are shown as blue diamonds, calculated as described in the text. Model-data comparisons are only shown for incubations at the PNM due to uncertainties in $\mathrm{NO}_{2}^{-}$removal above and below the PNM. Error bars reflect total uncertainty in the net $\mathrm{NO}_{2}^{-}$production calculation.

was the source of $\mathrm{NO}_{2}^{-}$in the upper PNM. However, direct measurements of $\mathrm{NO}_{2}^{-}$production via this pathway were not made. Although it may have contributed at rates below our detection limits, release of $\mathrm{NO}_{2}^{-}$from $\mathrm{NO}_{3}^{-}$was quite low at the depths of the PNM at our stations.

The potential for "bottle effects" causing either positive or negative impacts on the measured rates is always a consideration during at-sea incubation experiments. One such effect could be the potential for stimulation of the measured rates due to added substrate, particularly in the case of our ${ }^{15} \mathrm{NH}_{4}^{+}$ additions. Previous work in the open ocean (Olson, 1981a; Newell et al., 2013) suggests that environmental populations of ammonia oxidizers are saturated at $<100 \mathrm{nM} \mathrm{NH}_{4}^{+}$ with no rate stimulation beyond this concentration. Others have suggested large stimulation effects of $\mathrm{NH}_{4}^{+}$on nitrification (Horak et al., 2013). Cultures of ammonia-oxidizing archaea (Martens-Habbena et al., 2009) suggests that the halfsaturation constant $\left(K_{m}\right)$ for $\mathrm{NH}_{3}+\mathrm{NH}_{4}^{+}$is very low (less than $140 \mathrm{nM}$ ). At the depths of the PNM in the California Current, $\left[\mathrm{NH}_{4}^{+}\right]$was generally less than $100 \mathrm{nM}$, so it is possible that our $100 \mathrm{nM}^{15} \mathrm{NH}_{4}^{+}$additions could have stimulated ammonia oxidation. However, as noted above, the concentration of $\mathrm{NH}_{4}^{+}$decreased over the course of the experiment with no apparent decrease in the rate of ${ }^{15} \mathrm{NH}_{4}^{+}$conversion to $\mathrm{NO}_{2}^{-}$or $\mathrm{NO}_{2}^{-}+\mathrm{NO}_{3}^{-}$over time.

Because of the relatively short duration of the cruise, we were unable to start experiments from the two stations at 
similar times of day. As light is a potential contributing factor to the rates of ammonia oxidation and nitrate reduction, we evaluated the influence of light period on the measured rates of ${ }^{15} \mathrm{~N} /{ }^{14} \mathrm{~N}$ change in the intervals between each pair of time points. Changes in $\delta^{15} \mathrm{~N}$ over the course of the experiments were nearly linear and did not appear to be linked to the day-night cycle. This suggests that differential light exposure did not affect the relative rates measured at the two stations; however, this cannot be completely ruled out as a factor affecting our results.

A second potential issue with incubation experiments is saturation of ${ }^{15} \mathrm{~N} /{ }^{14} \mathrm{~N}$ in the product pool (in this case $\mathrm{NO}_{2}^{-}$), which would cause an underestimation in the rates of $\mathrm{NO}_{2}^{-}$ production. With a pool of $\mathrm{NO}_{2}^{-}$that is held at a constant steady-state concentration (inputs and outputs balanced), the time scale of $\mathrm{NO}_{2}^{-}$turnover that is required to saturate our ability to accurately model the input over 36 hours is on the order of $1 \mathrm{~d}^{-1}$. For example, a pool of $\mathrm{NO}_{2}^{-}$that is $100 \mathrm{nM}$ would show a plateau in the ${ }^{15} \mathrm{~N} /{ }^{14} \mathrm{~N}$ after $36 \mathrm{~h}$ at rates of production and consumption of $100 \mathrm{nMd}^{-1}$. This guideline is relevant to any size $\mathrm{NO}_{2}^{-}$pool that is turning over once per day and is insensitive to the substrate at $\%{ }^{15} \mathrm{~N}$ in the range used here for $\mathrm{NH}_{4}^{+}$oxidation (35-93\%) and $\mathrm{NO}_{3}^{-}$reduction (2-19\%). Rates this high were not observed in our experiments, and we never observed plateauing of $\delta^{15} \mathrm{~N}_{\mathrm{NO}_{2}}$ over time, or values approaching the initial at $\%{ }^{15} \mathrm{~N}$ of the substrate pool. Thus, we do not believe that the rates of $\mathrm{NO}_{2}^{-}$ production have been underestimated around the PNM. $\mathrm{NO}_{2}^{-}$ production could have been underestimated in the euphotic zone and at $500 \mathrm{~m}$, where the lack of measurable pre-existing $\mathrm{NO}_{2}^{-}$does not provide a trap for labeled $\mathrm{NO}_{2}^{-}$. Our interest, however, in this manuscript was in the formation and maintenance of the PNM, for which the above arguments hold.

In contrast to data from Station ALOHA (Dore and Karl, 1996b), we did not observe a "double peaked" PNM, though we have observed this feature on previous occupations of LINE 67 (Santoro et al., 2010). Dore and Karl observed an upper PNM (UPNM) and lower PNM (LPNM) that they attributed to $\mathrm{NO}_{3}^{-}$reduction and nitrification, respectively. They also detected $\mathrm{NO}_{2}^{-}$below the depth of the LPNM; $2-$ $5 \mathrm{nmol} \mathrm{L}-1 \mathrm{NO}_{2}^{-}$was present as deep as $800 \mathrm{~m}$. We did not find evidence of deep $\mathrm{NO}_{2}^{-}$, though measurements at $500 \mathrm{~m}$ and $1000 \mathrm{~m}$ were not made at every station. As suggested by Dore and Karl (1996b), this "tail" may be a result of episodic organic matter export events from the mixed layer not occurring during our cruise.

The patterns observed here in photosynthetic picoplankton distribution are consistent with previous observations from both the Atlantic (Zubkov et al., 2000; Cavender-Bares et al., 2001; Johnson et al., 2006) and Pacific. Zubkov et al. (2000) suggested that a high abundance of Synechococcus marked the transition between temperate and oligotrophic waters, consistent with the data presented here showing a high abundance of Synechococcus in $16^{\circ} \mathrm{C}$ waters. Deeper distribution of picoeukaryotes relative to picocyanobacteria has been observed at Station ALOHA (Campbell and Vaulot, 1993; Campbell et al., 1997), consistent with observations presented here. Due to the strong inverse correlation between temperature and $\left[\mathrm{NO}_{3}^{-}\right]$, the inverse correlation between Prochlorococcus abundance and $\left[\mathrm{NO}_{3}^{-}\right]$cannot be interpreted as a signal of $\mathrm{NO}_{3}^{-}$uptake by Prochlorococcus, but instead likely reflects the strong influence of temperature on the distribution of these organisms (Zubkov et al., 2000; Johnson et al., 2006; Zinser et al., 2007). Previous work in the Sargasso Sea (Zinser et al., 2007) did not find a correlation between Synechococcus abundance and temperature as we report here.

We used flow cytometry as an alternative to qPCR to target potentially nitrate-assimilating taxa. Nitrate reductase (Nar), the enzyme encoding the first step of assimilatory nitrate reduction, has a broad phylogenetic distribution, and it would be impossible to capture the majority of nitrate-reducing taxa with two or perhaps even ten sets of qPCR primers. Capturing cyanobacterial narB diversity alone requires a nested PCR assay not suitable for qPCR (Paerl et al. 2008), and 7 sets of qPCR primers to cover different Synechococcus ecotypes of narB alone (Paerl et al. 2011). Paerl et al. (2011) found that their qPCR assay for narB gave about $40 \%$ of the abundance estimate of flow cytometric Synechococcus counts. We also did not quantify heterotrophic organisms that may be responsible for $\mathrm{NO}_{3}^{-}$reduction, and some previous studies have shown variable but significant contributions of bacterioplankton to total $\mathrm{NO}_{3}^{-}$uptake in the upper ocean (4$14 \%$, Kirchman et al., 1994; 5-60\%, Kirchman and Wheeler 1998). The extent to which these organisms contribute to $\mathrm{NO}_{2}^{-}$production would have been captured by our $\mathrm{NO}_{3}^{-}$reduction rate measurements, even though we did not attempt to quantify the organisms.

The abundance of $\mathrm{AOA}$ relative to $\mathrm{AOB}$ was greater at station 67.155 (AOA : AOB >2000) in the oligotrophic waters of the North Pacific Gyre than at the upwelling station 67.70 (AOA: AOB 10-400), supporting previous speculation that AOA in the ocean are oligotrophic specialists (Martens-Habbena et al., 2009; Horak et al., 2013). The high relative abundance of the water column A amoA ecotype suggests this ecotype is responsible for the majority of the ammonia-oxidizing activity detected in our incubations. At present the physiological characteristics differentiating the two ecotypes is unknown (Beman et al., 2008; Santoro et al., 2010).

Sharp gradients were observed in nitrification rates, with apparent maxima just below the PNM at both stations. At 67.70 the maximum nitrification rate was coincident with the maximum AOA abundance below the PNM, whereas at 67.155 the abundance of AOA peaked within the PNM. Beman et al. (2012) also observed peaks in nitrification rates just below the PNM in the eastern tropical North Pacific using high-resolution measurements, particularly within 
Table 3. Compilation of residence time estimates of $\mathrm{NO}_{2}^{-}$in the primary nitrite maximum (PNM). When residence time was not explicitly reported in the original publication, residence time was determined as $\left[\mathrm{NO}_{2}^{-}\right]$/ production rate.

\begin{tabular}{|c|c|c|c|c|}
\hline Location & Depth & $\begin{array}{l}\text { Residence time } \\
\text { (d) }\end{array}$ & Method & Reference \\
\hline \multirow[t]{3}{*}{ Central California Current (St. 67.70) } & PNM & $270-470$ & ${ }^{15} \mathrm{~N}$ tracers & \multirow[t]{3}{*}{ This study } \\
\hline & PNM & 18 & 1-D model & \\
\hline & just below PNM & $4-9$ & ${ }^{15} \mathrm{~N}$ tracers & \\
\hline \multirow[t]{3}{*}{ Oligotrophic North Pacific (St. 67.155) } & PNM & 40 & ${ }^{15} \mathrm{~N}$ tracers & \multirow[t]{3}{*}{ This study } \\
\hline & PNM & 40 & 1-D model & \\
\hline & just below PNM & 3 & ${ }^{15} \mathrm{~N}$ tracers & \\
\hline Washington margin, inshore & PNM & 33 & ${ }^{15} \mathrm{~N}$ tracers & Ward et al. (1984) \\
\hline \multirow[t]{2}{*}{ Washington margin, offshore } & PNM & 10 & ${ }^{15} \mathrm{~N}$ tracers & Ward et al. (1984) \\
\hline & below PNM & 2 & ${ }^{15} \mathrm{~N}$ tracers & Ward et al. (1984) \\
\hline Hydrostation S/BATS & $100-300 \mathrm{~m}$, integrated & $4-7$ & {$\left[\mathrm{NO}_{2}^{-}\right]$- AOU relationships } & Lipschultz et al. (1996) \\
\hline \multirow{2}{*}{ Station ALOHA } & upper PNM & 13 & ${ }^{14} \mathrm{C}$ uptake & Dore and Karl (1996a) \\
\hline & PNM & 1 & ${ }^{14} \mathrm{C}$ uptake & Dore and Karl (1996a) \\
\hline \multirow[t]{2}{*}{ Arabian Sea } & PNM & $27-119$ & ${ }^{15} \mathrm{~N}$ tracers & Newell et al. (2011) \\
\hline & PNM & $33-427$ & $\delta^{18} \mathrm{O}_{\mathrm{NO}_{2}}$ model & Buchwald and Casciotti (2013) \\
\hline
\end{tabular}

the Gulf of California. Accumulation of $\mathrm{NO}_{2}^{-}$in the water column is not necessarily directly correlated to $\mathrm{NO}_{2}^{-}$ production, but rather reflects the balance of production and consumption of $\mathrm{NO}_{2}^{-}$. Thus, a spatial offset between maximal rates of production and $\left[\mathrm{NO}_{2}^{-}\right]$is not surprising. Newell et al. (2013), however, did observe a correspondence between the PNM and maximum nitrification rates in the Sargasso Sea.

A one-dimensional model was used to estimate $\mathrm{NO}_{2}^{-}$production rates from $\left[\mathrm{NO}_{2}^{-}\right]$profiles at station 67.70 and model the balance of biological production, consumption, and physical mixing (Fig. 5a, b). At station 67.70 (Fig. 5a), modeled $\mathrm{NO}_{2}^{-}$production within the PNM is roughly a factor of 10 greater than net production rates calculated using ${ }^{15} \mathrm{~N}$ rate measurements. Agreement between the model and measurements was better at station 67.155 (Fig. 5b). There are large uncertainties in the net $\mathrm{NO}_{2}^{-}$production calculation, as errors from all three rate determinations are propagated through the calculation and the model output is highly dependent on the choice of eddy diffusivity $\left(1.5 \times 10^{-4} \mathrm{~m}^{2} \mathrm{~s}^{-1}\right.$ used here $)$. Above and below the PNM, removal rates are poorly constrained by our ${ }^{15} \mathrm{~N}$ incubations because of large uncertainties in the removal rate constant $(k)$ and very low $\left[\mathrm{NO}_{2}^{-}\right]$. At these depths the 1-D model is probably a more accurate representation of net $\mathrm{NO}_{2}^{-}$production.

The mechanism that allows remineralization products $\left(\mathrm{NH}_{4}^{+}\right.$and $\left.\mathrm{NO}_{2}^{-}\right)$to accumulate is still uncertain. Differential light inhibition of the two nitrifier groups is often proposed (Olson, 1981b), whereby $\mathrm{NO}_{2}^{-}$oxidizers are inhibited at lower light levels (are more light sensitive) than ammonia oxidizers. Our data are consistent with this hypothesis; however, laboratory data suggest that AOA are also extremely light sensitive (Merbt et al., 2012), which argues against the differential light inhibition hypothesis. The extent to which these laboratory results reflect responses in nature is unclear, as extreme light sensitivity does not appear consistent with widespread presence of AOA amoA genes and transcripts in stratified Pacific surface waters (Church et al., 2010; Santoro et al., 2010).

Gradients in several other growth factors with "nutrientlike" depth distributions are seldom discussed, but equally plausible mechanisms for the accumulation of $\mathrm{NO}_{2}^{-}$at the PNM. Iron (Fe), in particular, could be limiting at the depth of the PNM. Non-steady-state Fe limitation is associated with $\mathrm{NO}_{2}^{-}$excretion in diatoms (Behrenfeld et al., 2006) and has been invoked to explain a potential phytoplankton source of $\mathrm{NO}_{2}^{-}$within the PNM (Lomas and Lipschultz, 2006). Fe could also play an underexplored role in a nitrificationsourced PNM. Our results indicate that AOA are both the most abundant and active nitrifiers at the PNM, as suggested previously (Mincer et al., 2007; Santoro et al., 2010; Newell et al., 2011). Genome analysis suggests AOA rely on blue copper proteins for respiration and electron transport (Walker et al., 2010; Blainey et al., 2011) and may therefore have a uniquely low $\mathrm{Fe}$ requirement. The nitrite oxidoreductase required for $\mathrm{NO}_{2}^{-}$oxidation, on the other hand, contains at least four $\mathrm{Fe}-\mathrm{S}$ clusters, suggesting a very high iron demand for this process (Kirstein and Bock, 1993; Spieck et al., 1998). Genomic information has only recently become available for relevant open-ocean $\mathrm{NO}_{2}^{-}$oxidizers, such as Nitrospina spp. (Mincer et al., 2007; Luecker et al., 2013), and is currently lacking for Nitrospira spp.

We measured low rates of $\mathrm{NO}_{2}^{-}$production from $\mathrm{NO}_{3}^{-}$at all stations and depths, arguing against a large role for $\mathrm{NO}_{2}^{-}$ excretion from phytoplankton in the formation of the PNM at these sites. Just below the PNM at $67.70, \mathrm{NO}_{2}^{-}$production from $\mathrm{NO}_{3}^{-}$was $2 \mathrm{nmol} \mathrm{L}^{-1} \mathrm{~d}^{-1}$ compared with mean rates of nitrification to $\mathrm{NO}_{2}^{-}$of $26 \mathrm{nmol} \mathrm{L}^{-1} \mathrm{~d}^{-1}$ and to $\mathrm{NO}_{2}^{-}+\mathrm{NO}_{3}^{-}$ 
of $33 \mathrm{nmol} \mathrm{L}^{-1} \mathrm{~d}^{-1}$. It should be stressed that low rates of $\mathrm{NO}_{2}^{-}$production from $\mathrm{NO}_{3}^{-}$measured using this technique should not be interpreted to mean there was little or no active assimilatory $\mathrm{NO}_{3}^{-}$reduction, or that $\mathrm{NO}_{3}^{-}$-based or "new" production is not important at these sites. Our data suggest only that any $\mathrm{NO}_{2}^{-}$produced during assimilatory $\mathrm{NO}_{3}^{-}$reduction does not escape the cell. Unfortunately, $\mathrm{NO}_{3}^{-}$uptake rates were not directly measured in our study, and there are few published $\mathrm{NO}_{3}^{-}$uptake data along Line 67 .

One possible explanation for the low rates of $\mathrm{NO}_{2}^{-}$production from $\mathrm{NO}_{3}^{-}$could be that phytoplankton $\mathrm{NO}_{2}^{-}$excretion only occurs under Fe-limited conditions. Our experiments were not performed using trace metal clean conditions, but variable fluorescence data $\left(F_{\mathrm{v}} / F_{\mathrm{m}}\right)$ taken over the course of the experiment do not suggest a fertilization effect of the incubation conditions (data not shown). $\mathrm{NO}_{2}^{-}$release by dinoflagellates has been observed in cells growing with both $\mathrm{NH}_{4}^{+}$and $\mathrm{NO}_{3}^{-}$(Flynn and Flynn, 1998). Thus, the low $\mathrm{NO}_{2}^{-}$ production rates observed in this study may indicate reliance on a single $\mathrm{N}$ source.

Previous studies that have attributed a large phytoplanktonic role in $\mathrm{NO}_{2}^{-}$production (Vaccaro and Ryther, 1960; Kiefer et al., 1976; Mackey et al., 2011) have interpreted correlations between $\mathrm{Chl} a$ stocks and $\mathrm{NO}_{2}^{-}$as evidence for phytoplankton production of $\mathrm{NO}_{2}^{-}$without direct measurements of $\mathrm{NO}_{2}^{-}$production from $\mathrm{NO}_{3}^{-}$. Grazing, lysis, and remineralization of $\mathrm{Chl} a$-containing organisms, however, could also account for correlations between $\mathrm{Chl} a$ and $\mathrm{NO}_{2}^{-}$. Our results for mixed-layer $\mathrm{NO}_{2}^{-}$production, showing rates of $\mathrm{NO}_{2}^{-}$ production from $\mathrm{NO}_{3}^{-}$exceeding $\mathrm{NH}_{3}$ oxidation, offer some support for the suggestion that mixed-layer $\mathrm{NO}_{2}^{-}$production shallower than the PNM (Al-Qutob et al., 2002) is the result of $\mathrm{NO}_{3}^{-}$reduction from either photolysis or active phytoplankton reduction.

The residence time of $\mathrm{NO}_{2}^{-}$within the PNM can be approximated from the concentration and the total $\mathrm{NO}_{2}^{-}$production rate, assuming steady state (Table 3). Residence times at the peak of the PNM are long - 270-470 days at the mesotrophic station and 40 days at the oligotrophic station. At the base of the PNM, residence times are much shorter 4-9 days at station 67.70 and 3 days at 67.155. Early investigations into the PNM (Kiefer and Kremer, 1981) suggested that the PNM is a relict feature of "old" $\mathrm{NO}_{2}^{-}$excreted during rapid phytoplankton growth. Our results support previous findings (Olson, 1981a; Ward et al., 1982; Dore and Karl, 1996a) that portions of the PNM reflect active and dynamic $\mathrm{N}$-cycling processes, while the peak reflects relatively slow biological turnover (Buchwald and Casciotti, 2013).

In summary, the results presented here strongly suggest that most $\mathrm{PNM} \mathrm{NO}_{2}^{-}$in the central California Current and offshore waters originates from $\mathrm{NH}_{4}^{+}$oxidation. If $\mathrm{NO}_{3}^{-}$reduction by phytoplankton does contribute to $\mathrm{NO}_{2}^{-}$accumulation, we suggest that it occurs intermittently and therefore was not captured by our incubation experiments. Our results help constrain possible sources of $\mathrm{NO}_{2}^{-}$within the PNM, but questions still remain about why $\mathrm{NO}_{2}^{-}$accumulates within this feature and is not consumed by nitrite-oxidizing bacteria. Rates of $\mathrm{NO}_{2}^{-}$-removal processes in oxic water columns are poorly constrained and merit further study. Accessing the natural abundance stable isotope ratios of $\mathrm{NO}_{2}^{-}$is now possible and may provide further insight into the mechanisms controlling $\mathrm{NO}_{2}^{-}$production and consumption in the PNM (Buchwald and Casciotti, 2013).

Acknowledgements. The authors acknowledge the Captain and crew of R/V Western Flyer, Marguerite Blum, Ginger Elrod, Matt McIlvin, and Tim Pennington, for assistance in the laboratory and at sea. We thank Sylvia Newell for providing rate data from the Arabian Sea in tabular format. Carolyn Buchwald provided helpful comments on the manuscript. A. E. Santoro was funded by a Woods Hole Oceanographic Institution Postdoctoral Scholar Fellowship and startup funds from the University of Maryland Center for Environmental Science (UMCES). Support was also provided by NSF-OCE award \#0961098 to K. L. Casciotti. This is UMCES contribution number 4818 .

Edited by: G. Herndl

\section{References}

Al-Qutob, M., Hase, C., Tilzer, M. M., and Lazar, B.: Phytoplankton drives nitrite dynamics in the Gulf of Aqaba, Red Sea. Mar. Ecol. Prog. Ser., 239, 233-239, 2002.

Allen, A. E., Booth, M. G., Frischer, M. E., Verity, P. G., Zehr, J. P., and Zani, S.: Diversity and detection of nitrate assimilation genes in marine bacteria, Appl. Environ. Microbiol., 67, 53435348, 2001.

Archer, D., Emerson, S., Powell, T., and Wong, C. S.: Numerical hindcasting of sea surface $p \mathrm{CO}_{2}$ at Weathership Station Papa, Prog. Oceanogr., 32, 319-351, 1993.

Babu, K. N., Sharma, R., Agarwal, N., Agarwal, V. K., and Weller, R. A.: Study of the mixed layer depth variations within the north Indian Ocean using a 1-D model, J. Geophys. Res., 109, C08016, doi:10.1029/2003JC002024, 2004.

Behrenfeld, M. J., O’Malley, R. T., Siegel, D. A., McClain, C. R., Sarmiento, J. L., Feldman, G. C., Milligan, A. J., Falkowski, P. G., Letelier, R. M., and Boss, E. S.: Climate-driven trends in contemporary ocean productivity, Nature, 444, 752-755, 2006.

Beman, J. M., Popp, B. N., and Francis, C. A.: Molecular and biogeochemical evidence for ammonia oxidation by marine Crenarchaeota in the Gulf of California, ISME Journal, 2, 429-441, 2008.

Beman, J. M., Sachdeva, R., and Fuhrman, J. A.: Population ecology of nitrifying archaea and Bacteria in the Southern California Bight, Environ. Microbiol., 12, 1282-1292, 2010.

Beman, J. M., Popp, B. N., and Alford, S. E.: Quantification of ammonia oxidation rates and ammonia-oxidizing archaea and bacteria at high resolution in the Gulf of California and eastern tropical North Pacific Ocean, Limnol. Oceanogr., 57, 711-726, 2012.

Blainey, P. C., Mosier, A. C., Potanina, A., Francis, C. A., Quake, S. R., and Gilbert, J.: Genome of a low-salinity ammonia-oxidizing 
archaeon determined by single-cell and metagenomic analysis, PLoS One, 6, 148-149, 2011.

Brandhorst, W.: Nitrification and denitrification in the eastern tropical North Pacific, J. Conseil Perm. Int. Expl. Mer., 25, 2-20, 1959.

Buchwald, C. and Casciotti, K. L.: Oxygen isotopic fractionation and exchange during bacterial nitrite oxidation, Limnol. Oceanogr., 55, 1064-1074, 2010.

Buchwald, C. and Casciotti, K. L.: Isotopic ratios of nitrite as tracers of the source and age of oceanic nitrite, Nat. Geosci., 6, 4, 308313, doi:10.1038/NGEO1745, 2013.

Buchwald, C., Santoro, A. E., McIlvin, M. R., and Casciotti, K. L.: Oxygen isotopic composition of nitrate and nitrite produced by nitrifying cocultures and natural marine assemblages, Limnol. Oceanogr., 57, 1361-1375, 2012.

Campbell, L. and Vaulot, D.: Photosynthetic picoplankton community structure in the subtropical north Pacific-Ocean near Hawaii (Station AlOHA), Deep-Sea Res. I, 40, 2043-2060, 1993.

Campbell, L., Liu, H. B., Nolla, H. A., and Vaulot, D.: Annual variability of phytoplankton and bacteria in the subtropical North Pacific Ocean at Station ALOHA during the 1991-1994 ENSO event, Deep Sea Res. I, 44, 167-192, 1997.

Casciotti, K. L., and McIlvin, M. R.: Isotopic analyses of nitrate and nitrite from reference mixtures and application to Eastern Tropical North Pacific waters, Mar. Chem., 107, 184-201, 2007.

Casciotti, K. L., Sigman, D. M., Hastings, M. G., Bohlke, J. K., and Hilkert, A.: Measurement of the oxygen isotopic composition of nitrate in seawater and freshwater using the denitrifier method, Anal. Chem., 74, 4905-4912, 2002.

Casciotti, K. L., Bohlke, J. K., McIlvin, M. R., Mroczkowski, S. J., and Hannon, J. E.: Oxygen isotopes in nitrite: Analysis, calibration, and equilibration, Anal. Chem., 79, 2427-2436, 2007.

Casciotti, K. L., McIlvin, M. R., and Buchwald, C.: Oxygen isotopic exchange and fractionation during bacterial ammonia oxidation, Limnol. Oceanogr, 55, 753-762, 2010.

Casey, J. R., Lomas, M. W., Mandecki, J., and Walker, D. E.: Prochlorococcus contributes to new production in the Sargasso Sea deep chlorophyll maximum, Geophys. Res. Lett., 34, L10604, doi:10.1029/2006GL028725, 2007.

Cavender-Bares, K. K., Karl, D. M., and Chisholm, S. W.: Nutrient gradients in the western North Atlantic Ocean: Relationship to microbial community structure and comparison to patterns in the Pacific Ocean, Deep Sea Res. I, 48, 2373-2395, 2001.

Church, M. J., Karl, D. M., and DeLong, E. F.: Abundances of crenarchaeal amoA genes and transcripts in the Pacific Ocean, Environ. Microbiol., 12, 679-688, 2010.

Codispoti, L. A., Friederich, G. E., Packard, T. T., Glover, H. E., Kelly, P. J., Spinrad, R. W., Barber, R. T., Elkins, J. W., Ward, B. B., Lipschultz, F., and Lostaunau, N.: High nitrite levels off northern Peru - a signal of instability in the marine denitrification rate, Science, 233, 1200-1202, 1986.

Collins, C. A., Pennington, J. T., Castro, C. G., Rago, T. A., and Chavez, F. P.: The California Current system off Monterey, California: physical and biological coupling, Deep Sea Res. II, 50, 2389-2404, 2003.

Cuvelier, M. L., Allen, A. E., Monier, A., McCrow, J. P., Messie, M., Tringe, S. G., Woyke, T., Welsh, R. M., Ishoey, T., Lee, J. H., Binder, B. J., DuPont, C. L., Latasa, M., Guigand, C., Buck, K. R., Hilton, J., Thiagarajan, M., Caler, E., Read, B., Lasken,
R. S., Chavez, F. P., and Worden, A. Z.: Targeted metagenomics and ecology of globally important uncultured eukaryotic phytoplankton, Proc. Natl. Acad. Sci. USA, 107, 14679-14684, 2010.

Dore, J. E. and Karl, D. M.: Nitrification in the euphotic zone as a source for nitrite, nitrate, and nitrous oxide at Station ALOHA, Limnol. Oceanogr., 41, 1619-1628, 1996a.

Dore, J. E. and Karl, D. M.: Nitrite distributions and dynamics at station ALOHA, Deep Sea Res., 43, 385-402, 1996 b.

Dugdale, R. C. and Goering, J. J.: Uptake of new and regenerated forms of nitrogen in primary productivity, Limnol. Oceanogr., 12, 196-206, 1967.

Eppley, R. W., Coatswor. J., and Solorzano, L.: Studies of nitrate reductase in marine phytoplankton, Limnol. Oceanogr., 14, 194 205, 1969.

Fawcett, S. E., Lomas, M., Casey, J. R., Ward, B. B., and Sigman, D. M.: Assimilation of upwelled nitrate by small eukaryotes in the Sargasso Sea, Nat. Geosci., 4, 717-722, 2011.

Flynn, K. J., and Flynn, K.: Release of nitrite by marine dinoflagellates: development of a mathematical simulation, Mar. Biol., 130, 455-470, 1998.

Francis, C. A., Roberts, K. J., Beman, J. M., Santoro, A. E., and Oakley, B.B.: Ubiquity and diversity of ammonia-oxidizing archaea in water columns and sediments of the ocean, Proc. Natl. Acad. Sci. USA, 102, 14683-14688, 2005.

Glover, D. M., Jenkins, B. D., and Doney, S. C: Modeling Methods for Marine Science, Cambridge University Press, Cambridge, 2011.

Hallam, S. J., Mincer, T. J., Schleper, C., Preston, C. M., Roberts, K., Richardson, P. M., and DeLong, E. F.: Pathways of carbon assimilation and ammonia oxidation suggested by environmental genomic analyses of marine Crenarchaeota, PLoS Biology, 4, 520-536, 2006.

Horak, R. E. A., Qin, W., Shauer, A. J., Armbrust, E. V., Ingalls, A. E., Moffett, J. W., Stahl, D. A., and Devol, A. H.: Ammonia oxidation kinetics and temperature sensitivity of a natural marine community dominated by archaea, ISME J., 7, 10, 2023-2033, 2013.

Jenkins, B. D., Zehr, J. P., Gibson, A., and Campbell, L.: Cyanobacterial assimilatory nitrate reductase gene diversity in coastal and oligotrophic marine environments, Environ. Microbiol., 8, 2083 2095, 2006.

Johnson, K. S. and Coletti, L. J.: In situ ultraviolet spectrophotometry for high resolution and long-term monitoring of nitrate, bromide and bisulfide in the ocean, Deep Sea Res. I, 49, 1291-1305, 2002.

Johnson, Z. I., Zinser, E. R., Coe, A., McNulty, N. P., Woodward, E. M. S., and Chisholm, S. W.: Niche partitioning among Prochlorococcus ecotypes along ocean-scale environmental gradients, Science, 311, 1737-1740, 2006.

Kalnay, E., Kanamitsu, M., Kistler, R., Collins, W., Deaven, D., Gandin, L., Iredell, M., Saha, S., White, G., Woollen, J., Zhu, Y., Chelliah, M., Ebisuzaki, W., Higgins, W., Janowiak, J., Mo, K.C., Ropelewski, C., Wang, J., Leetmaa, A., Reynolds, R., Jenne, R., and Joseph, D.: The NCEP/NCAR 40-year reanalysis project, B. Am. Meteorol. Soc., 77, 437-471, 1996.

Karl, D. M., Bidigare, R. R., Church, M. J., Dore, J. E., Letelier, R. M., Mahaffey, C., and Zehr, J. P.: The Nitrogen cycle in the North Pacific trades biome: An evolving paradigm, in: Nitrogen in the Marine Environment, edited by: Capone, D. G., Bronk, D. 
A., Mulholland, M. R., and Carpenter, E. J., 2nd Edn., Elsevier, 705-770, 2008.

Kiefer, D. A. and Kremer, J. N.: Origins of vertical patterns of phytoplankton and nutrients in the temperate, open ocean - a stratigraphic hypothesis, Deep-Sea Res. I, 28, 1087-1105, 1981.

Kiefer, D. A., Olson, R. J., and Holmhansen, O.: Another look at nitrite and chlorophyll maxima in central north Pacific, Deep-Sea Res., 23, 1199-1208, 1976.

Kirstein, K. and Bock, E.: Close genetic-relationship between Nitrobacter-hamburgensis nitrite oxidoreductase and Escherichia-coli nitrate reductases, Arch. Microbiol., 160, 447453, 1993.

Lipschultz, F., Zafiriou, O. C., and Ball, L. A.: Seasonal fluctuations of nitrite concentrations in the deep oligotrophic ocean, Deep Sea Res., 43, 403-419, 1996.

Lomas, M. W. and Lipschultz, F.: Forming the primary nitrite maximum: Nitrifiers or phytoplankton?, Limnol. Oceanogr., 51, 2453-2467, 2006.

Luecker, S., Nowka, B., Rattei, T., Spieck, E., and Daims, H.: The genome of Nitrospina gracilis illuminates the metabolism and evolution of the major marine nitrite oxidizer, Frontiers in Microbiology, 4, 2013.

Mackey, K. R. M., Bristow, L., Parks, D. R., Altabet, M. A., Post, A. F., and Paytan, A.: The influence of light on nitrogen cycling and the primary nitrite maximum in a seasonally stratified sea, Prog. Oceanogr., 91, 545-560, 2011.

Martens-Habbena, W., Berube, P. M., Urakawa, H., de la Torre, J. R., and Stahl, D. A.: Ammonia oxidation kinetics determine niche separation of nitrifying archaea and Bacteria, Nature, 461, 976-981, 2009.

Martiny, A. C., Kathuria, S., and Berube, P. M.: Widespread metabolic potential for nitrite and nitrate assimilation among Prochlorococcus ecotypes, Proc. Natl. Acad. Sci. USA, 106, 10787-10792, 2009.

Martz, T. R., DeGrandpre, M. D., Strutton, P. G., McGillis, W. R., and Drennan, W. M.: Sea surface $p \mathrm{CO}_{2}$ and carbon export during the Labrador Sea spring-summer bloom: An in situ mass balance approach, J. Geophys. Res., 114, C09008, doi:10.1029/2008JC005060, 2009.

Mathieu, T. and Deyoung, B.: Application of a Mixed-Layer Model to the Inner Newfoundland Shelf, J. Geophys. Res., 100, 921936, 1995

McIlvin, M. R. and Altabet, M. A.: Chemical conversion of nitrate and nitrite to nitrous oxide for nitrogen and oxygen isotopic analysis in freshwater and seawater, Anal. Chem., 77, 5589-5595, 2005.

McIlvin, M. R. and Casciotti, K. L.: Technical updates to the bacterial method for nitrate isotopic analyses, Anal. Chem., doi:10.1021/ac1028984, 2011.

Mincer, T. J., Church, M. J., Taylor, L .T., Preston, C., Karl, D. M., and DeLong, E. F.: Quantitative distribution of presumptive archaeal and bacterial nitrifiers in Monterey Bay and the North Pacific Subtropical Gyre, Environ. Microbiol., 9, 1162-1175, 2007.

Mosier, A. C. and Francis, C. A.: Determining the distribution of marine and coastal ammonia-oxidizing archaea and bacteria using a quantitative approach, Methods Enzymol., 486, 205-221, 2011.

Murray, A. E., Blakis, A., Massana, R., Strawzewski, S., Passow, U., Alldredge, A., and DeLong, E. F.: A time series assessment of planktonic archaeal variability in the Santa Barbara Channel, Aquat. Microb. Ecol., 20, 129-145, 1999.

Naqvi, S., Yoshinari, T., Jayakumar, D., Altabet, M., Narvekar, P., Devol, A., Brandes, J., and Codispoti, L.: Budgetary and biogeochemical implications of $\mathrm{N} 2 \mathrm{O}$ isotope signatures in the Arabian Sea, Nature, 394, 462-464, 1998.

Newell, S. E., Babbin, A. R., Jayakumar, A., and Ward, B. B.: Ammonia oxidation rates and nitrification in the Arabian Sea, Global Biogeochem. Cy., 25, Gb4016, doi:10.1029/2010GB003940, 2011.

Newell, S. E., Fawcett, S. E., and Ward, B. B.: Depth distribution of ammonia oxidation rates and ammonia-oxidizer community composition in the Sargasso Sea, Limnol. Oceanogr., 58, 1491$1500,2013$.

Olson, R. J.: ${ }^{15} \mathrm{~N}$ tracer studies of the primary nitrite maximum, $\mathrm{J}$ Mar. Res., 39, 203-226, 1981a.

Olson, R. J.: Differential photoinhibition of marine nitrifying bacteria: a possible mechanism for the formation of the primary nitrite maximum, J. Mar. Res., 39, 227-238, 1981b.

Paerl, R. W., Foster, R. A., Jenkins, B. D., Montoya, J. P., and Zehr, J. P.: Phylogenetic diversity of cyanobacterial narB genes from various marine habitats, Environ. Microbiol., 10, 3377-3387, 2008.

Paerl, R. W., Tozzi, S., Kolber, Z. S., and Zehr, J. P.: Variation in the abundance of Synechococcus sp. CC9311 narB mRNA relative to changes in light, nitrogen growth conditions and nitrate assimilation, J. Phycol., 48, 1028-1039, 2012.

Patey, M. D., Rijkenberg, M. J. A., Statham, P. J., Stinchcombe, M. C., Achterberg, E. P., and Mowlem, M.: Determination of nitrate and phosphate in seawater at nanomolar concentrations, TracTrend Anal. Chem., 27, 169-182, 2008.

Plant, J. N., Johnson, K. S., Needoba, J. A., and Coletti, L. J.: NH4Digiscan: an in situ and laboratory ammonium analyzer for estuarine, coastal, and shelf waters, Limnol. Oceanogr.-Meth., 7 , 144-156, 2009.

Plueddemann, A. J., Weller, R. A., Stramska, M., Dickey, T. D., and Marra, J.: Vertical structure of the upper ocean during the marine light-mixed layers experiment, J. Geophys. Res., 100, 66056619, 1995.

Price, J. F., Weller, R. A., and Pinkel, R.: Diurnal cycling - observations and models of the upper ocean response to diurnal heating,cooling, and wind mixing, J. Geophys. Res., 91, 8411-8427, 1986.

Raimbault, P., Garcia, N., and Cerutti, F.: Distribution of inorganic and organic nutrients in the South Pacific Ocean - evidence for long-term accumulation of organic matter in nitrogendepleted waters, Biogeosciences, 5, 281-298, doi:10.5194/bg-5281-2008, 2008

Rocap, G., Larimer, F. W., Lamerdin, J., Malfatti, S. A., Chain, P., Ahlgren, N. A., Arellano, A., Coleman, M. L., Hauser, L., Hess, W. R., Johnson, Z. I., Land, M., Lindell, D., Post, A. F., Regala, W., Shah, M., Shaw, S. L., Steglich, C., Sullivan, M. B., Ting, C. S., Tolonen, A., Webb, E. A., Zinser, E. R., and Chisholm, S. W.: Genome divergence in two Prochlorococcus ecotypes reflects oceanic niche differentiation, Nature, 424, 1042-1047, 2003.

Sakamoto, C. M., Friederich, G. E., and Codispoti, L. A.: MBARI procedures for automated nutrient analyses using a modified Alpkem Series 300 Rapid Flow Analyzer, in: MBARI Technical Re- 
port, 90-2, (Moss Landing, CA: Monterey Bay Aquarium Research Institute), 1990.

Santoro, A. E. and Casciotti, K. L.: Enrichment and characterization of ammonia-oxidizing archaea from the open ocean: Phylogeny, physiology, and stable isotope fractionation, ISME J., 5, 17961808, doi:10.1038/ismej.2011.1058, 2011.

Santoro, A. E., Casciotti, K. L., and Francis, C. A.: Activity, abundance and diversity of nitrifying archaea and bacteria in the central California Current, Environ. Microbiol., 12, 1989-2006, 2010.

Sigman, D. M., Casciotti, K. L., Andreani, M., Barford, C., Galanter, M., and Bohlke, J. K.: A bacterial method for the nitrogen isotopic analysis of nitrate in seawater and freshwater, Anal. Chem., 73, 4145-4153, 2001.

Signorini, S. R., McClain, C. R., Christian, J. R., and Wong, C. S.: Seasonal and interannual variability of phytoplankton, nutrients, $\mathrm{TCO}_{2}, p \mathrm{CO}_{2}$ ), and $\mathrm{O}_{2}$ ) in the eastern subarctic Pacific (ocean weather station Papa), J. Geophys. Res., 106, $31197-$ 31215, 2001.

Spieck, E., Ehrich, S., Aamand, J., and Bock, E.: Isolation and immunocytochemical location of the nitrite-oxidizing system in Nitrospira moscoviensis, Arch. Microbiol., 169, 225-230, 1998.

Su, H., Cheng, Y. F., Oswald, R., Behrendt, T., Trebs, I., Meixner, F. X., Andreae, M. O., Cheng, P., Zhang, Y., and Poschl, U.: Soil nitrite as a source of atmospheric $\mathrm{HONO}$ and $\mathrm{OH}$ radicals, Science, 333, 1616-1618, 2011.

Vaccaro, R. and Ryther, J. H.: Marine phytoplankton and the distribution of nitrite in the sea, J. Conseil Perm. Int. Expl. Mer., 25, 260-271, 1960.

Vage, K., Pickart, R. S., Moore, G. W. K., and Ribergaard, M. H.: Winter mixed layer development in the central Irminger Sea: The effect of strong, intermittent wind events, J. Phys. Oceanogr., 38, 541-565, 2008.

Venrick, E. L. and Hayward, T.L.: Determining chlorophyll on the 1984 CalCOFI surveys, Cal Coop Ocean Fish, 25, 74-79, 1984.

Wada, E. and Hattori, A.: Nitrite metabolism in euphotic layer of the central North Pacific Ocean, Limnol. Oceanogr., 16, 766$772,1971$.
Walker, C. B., de la Torre, J. R., Klotz, M. G., Urakawa, H., Pinel, N., Arp, D. J., Brochier-Armanet, C., Chain, P. S. G., Chan, P. P., and Gollabgir, A.: Nitrosopumilus maritimus genome reveals unique mechanisms for nitrification and autotrophy in globally distributed marine crenarchaea, Proc. Natl. Acad. Sci. USA, 107, 8818-8823, 2010.

Ward, B. B.: Nitrification in aquatic environments, in: Encyclopedia of environmental microbiology, edidet by: Capone, D. G., New York, John Wiley and Sons, 2144-2167, 2002.

Ward, B. B.: Phytoplankton community composition and gene expression of functional genes involved in carbon and nitrogen assimilation, J. Phycol., 44, 1490-1503, 2008.

Ward, B. B. and Zafiriou, O. C.: Nitrification and nitric oxide in the oxygen minimum of the Eastern Tropical North Pacific, Deep Sea Res. I, 35, 1127-1142, 1988.

Ward, B. B., Olson, R. J., and Perry, M. J.: Microbial nitrification rates in the primary nitrite maximum off Southern-California, Deep Sea Res. I, 29, 247-255, 1982.

Ward, B. B., Talbot, M. C., and Perry, M.,J.: Contributions of phytoplankton and nitrifying bacteria to ammonium and nitrite dynamics in coastal waters, Cont. Shelf Res., 3, 383-398, 1984.

Zafiriou, O. C. and Mcfarland, M.: Nitric-oxide from nitrite photolysis in the central Equatorial Pacific, J. Geophys. Res.-Oc. Atmos., 86, 3173-3182, 1981.

Zafiriou, O. C. and True, M. B.: Nitrite photolysis as a source of free-radicals in productive surface waters, Geophys. Res. Lett., 6, 81-84, 1979a.

Zafiriou, O. C. and True, M. B.: Nitrite photolysis in seawater by sunlight, Mar. Chem., 8, 9-32, 1979 b.

Zhang, J. Z.: Shipboard automated determination of trace concentrations of nitrite and nitrate in oligotrophic water by gassegmented continuous flow analysis with a liquid waveguide capillary flow cell, Deep Sea Res. I, 47, 1157-1171, 2000.

Zinser, E. R., Johnson, Z. I., Coe, A., Karaca, E., Veneziano, D., and Chisholm, S. W.: Influence of light and temperature on Prochlorococcus ecotype distributions in the Atlantic Ocean, Limnol. Oceanogr., 52, 2205-2220, 2007.

Zubkov, M. V., Sleigh, M. A., Burkill, P. H., and Leakey, R. J. G.: Picoplankton community structure on the Atlantic Meridional Transect: a comparison between seasons, Prog. Oceanogr., 45, 369-386, 2000. 